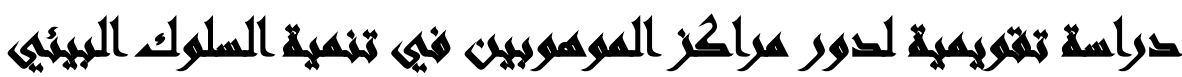

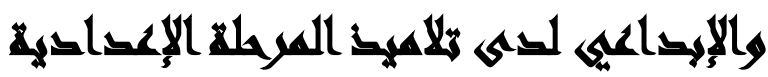

\author{
محمدعبد التواب عبد المولى(')- مصطفى إبراهيم عوض(ץ) - شيماء بدر(ץ)

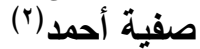 \\ () طالب دراسات عليا، معهد الدراسات والبحوث البيئية، جامعة عين شمس r ؟) معهد

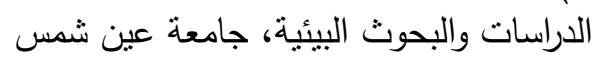

\section{المستخلم:}

هدف هذا البحث إلى تقويم دور مراكز الموهوبين في تتمية السلوك البيئي والإبداعي

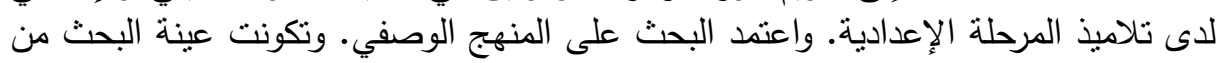

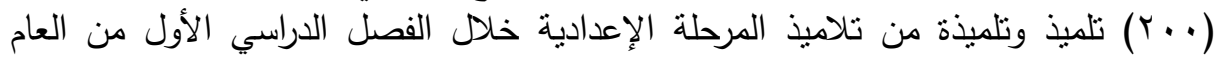

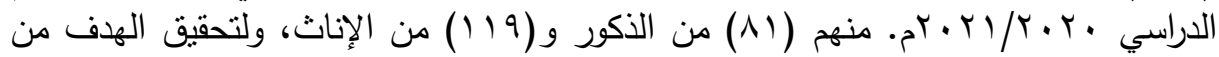

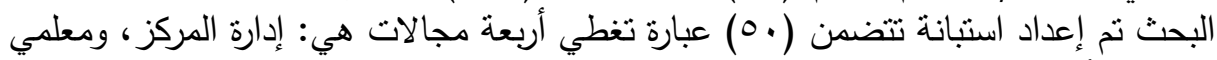

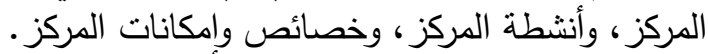

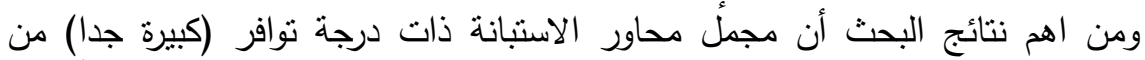

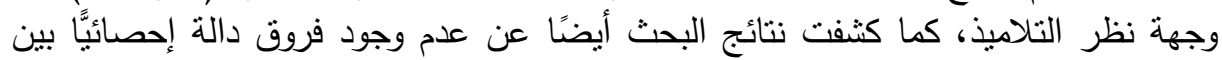

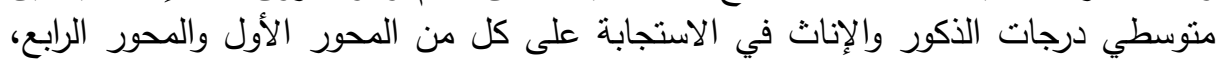

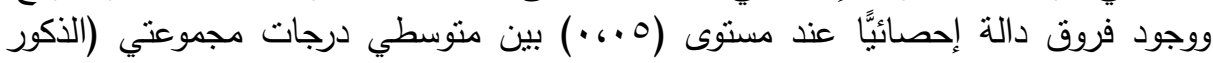

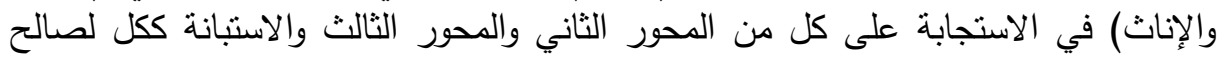

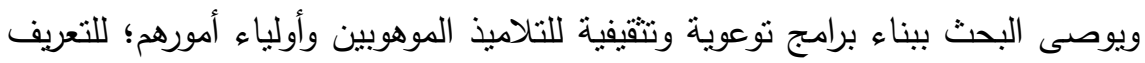

$$
\text { - مالذكور }
$$

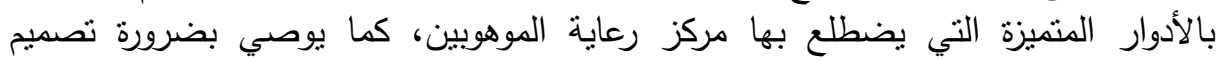

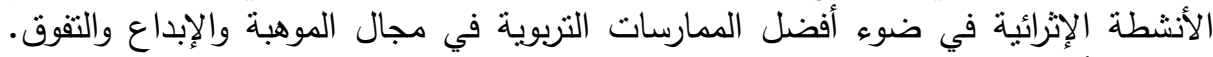

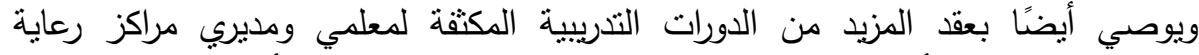
الموهوبين لنزويدهم بأحدث المستجدات في المجال. وإيلاء وتوجيه قدر أكبر من العناية بقياس

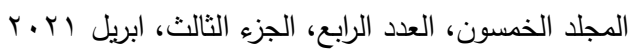

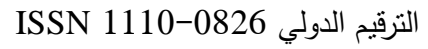


وتقويم مدى فاعلية مراكز رعاية الموهوبين - من وجهات نظر كافة الأطراف ذات الصلة -

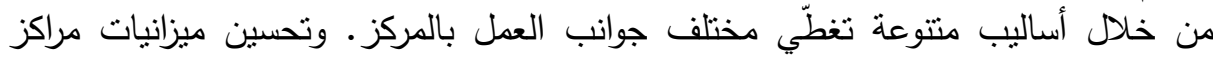

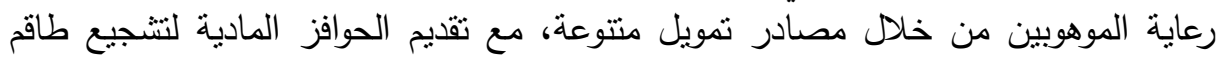

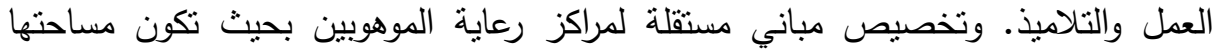
مناسبة، وتتسع لممارسة مختلف الأنشطة والفعاليات المبات المستهدفة. الكلمات المفتاحية: مراكز الموهوبين - السلوك البيئي - السلوك الإبداعي.

\section{$x$}

تسعى الأمم جاهدةً إلى استثمار طاقاتها وثرواتها وخاصة الثروة البشرية التي تمنل عماد الأمة، ويأتي التلاميذ المبدعون والموهوبون في مقدمة تلك الثروة البشرية؛ حيث إنَّ تلك الفئة

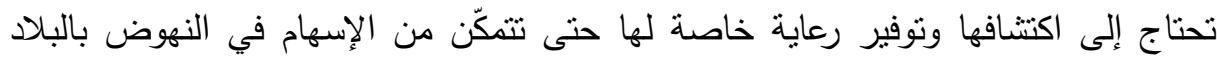
مستقبلًا، وتقوم بدورها الفعّال نحو تحقيق التتمية الثاملة والمستدامة.

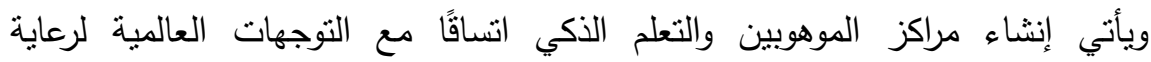
الموهوبين والمتقوقين والمبدعين، وتلبية لتوصبات الباحثين والمتخصصين في هذه المجالات، كما يعبر عن سعي جمهورية مصر العربية لمواكبة دول العالم المتقدم في الاعتتاء بهذه الفئة

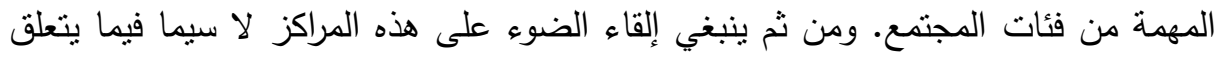
بالجهود المبذولة للقيام بدورها في تتمية السلوك البيئي والإبداعي لاى التلاميذ المترددين عليها من الموهوبين والمتفوقين والمبدعين.

وقد لمس الباحث وجود فجوة بحثية في مجال قياس وتقويم دور مراكز الموهوبين؛ حيث

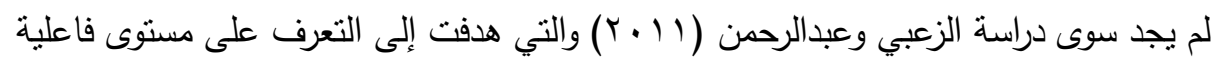
مركز رعاية الموهوبين والموهوبات من وجهة نظر الطلبة الملتحقين به، ولم تكن هذه الدراسة بمصر بل كانت بالمملكة العربية السعودية؛ مما بدل على مدى الحاجة لإجراء الدراسة 


\section{And}

يسعى المجتمع المصري كغيره من المجتمعات إلى الرقي والتقدم واستثمار طاقاته البشرية وذلك من خلال مؤسسات تربوية تهتم بالطلاب الموهوبين وتعمل على اكتتافهم وتقديم الدعم الكامل لهذه الفئة من الطلاب. وحتى تستمر هذه المؤسسات التربوية في الاضطلاع بأدوارها المهمة والنهوض بمسئولياتها ورسالتها السامية لا بد من تقويم أدائها؛ للوقوف على نقاط القوة

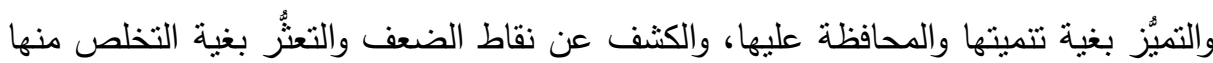
ومعالجة الآثار المترتبة عليها.

وقد اتضح وجود مشكلة البحث الحالي من خلال الزيارات الميدانية التي يقوم بها الباحثون بحكم عمله مديرًا عامَّا للإدارة العامة للتعليم العام بمحافظة القاهرة؛ حيث لاحظ أن الن

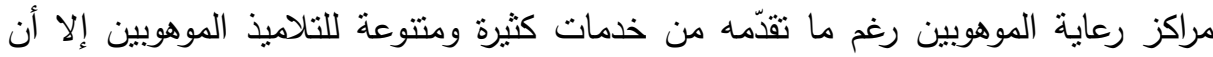

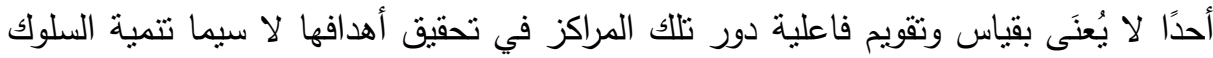
البيئي والإبداعي لدى التلاميذ؛ مما يترتب عليه أن يستمر العمل بهذه المراكز دون موجِّهات

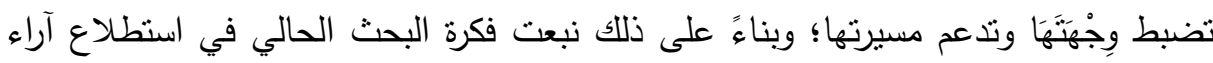
التلاميذ الموهوبين بالمرحلة الإعدادية للوقوف على تصوراتهم وتوجهاتهم نحو دور مراكز الموهوبين في تتمية السلوك البيئي والإبداعي. وقد قام الباحث بعمل بعض الجلسات النقاشية واللقاءات المفتوحة مع التلاميذ المترددين

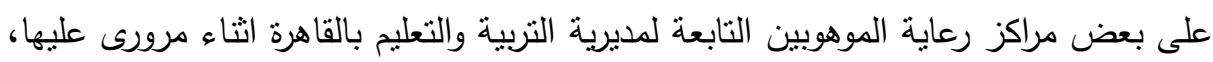

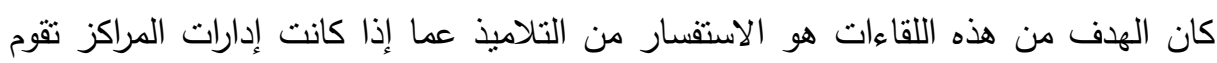

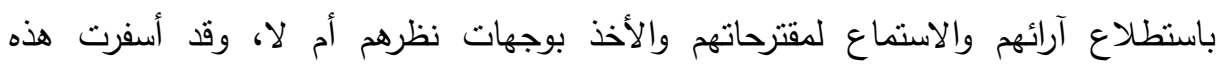
المقابلات واللقاءات عن عدم قيام أي مسؤول من داخل أو خارج المراكز باستطلاع آرائهم 
للكثف عن فاعلية دور مراكز رعاية الموهوبين في تتمية جوانب شخصياتهم لا سيما السلوك

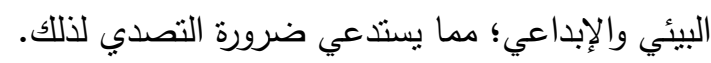

\section{أسهلم المهيث}

السؤال الرئيسي: ما مدى نجاح مراكز الموهوبين بمديرية التربية والتعليم بالقاهرة في تتمية السلوك البيئي والإبداعي لدى التلاميذ الموهوبين بالمرحلة الإعدادية؟ ماتج وقد تفرع من هذا السؤال الرئيسي الأسئلة الفرعية الآتية:

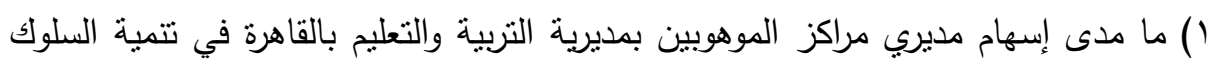

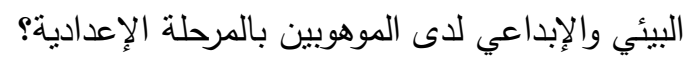

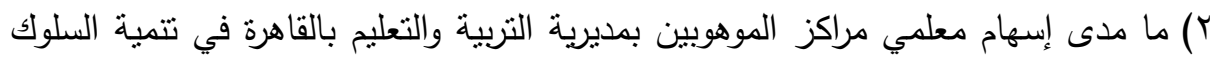

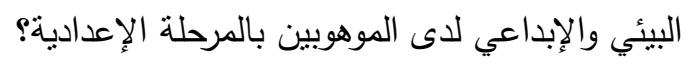

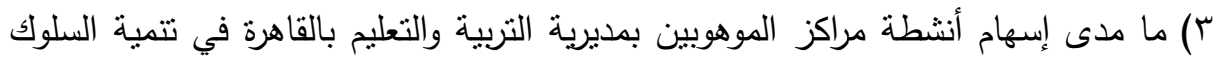

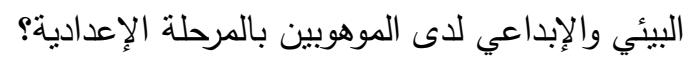

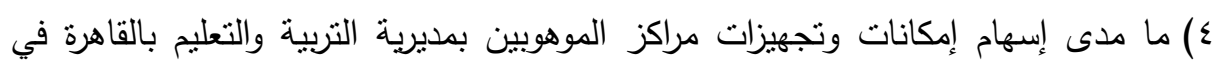

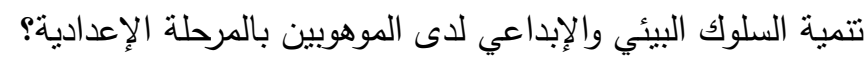

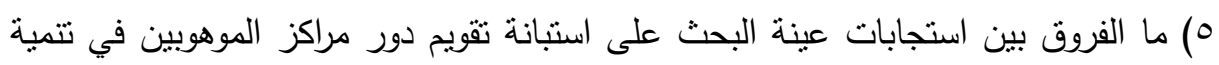
السلوك البيئي والإبداعي لدى تلاميذ المرحلة الإعدادية تبعًا لمتغير النوع (ذكور ، إناث)؟ لينّابه

\section{أهمية الهيهي}

يمثل الاهتمام بالموهوبين والتعرف على الموهبة ورعايتها منذ الصغر وتوفير البيئة

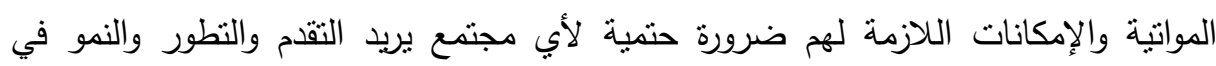
ميادين العلم والمعرفة الإنسانية في عصر لا يعرف إلا التفوق في العقل والإبداع في الفكر لئر 170

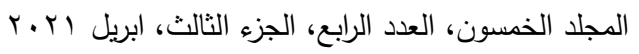

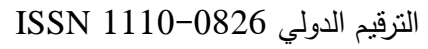


وقد استمد البحث الحالي أهميته من وجود فجوة بحثية تتمثل في عدم وجود دراسات مصرية -

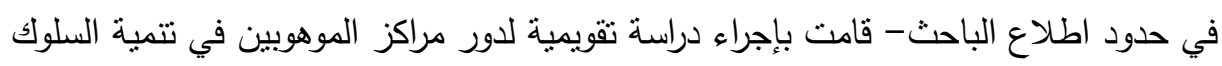

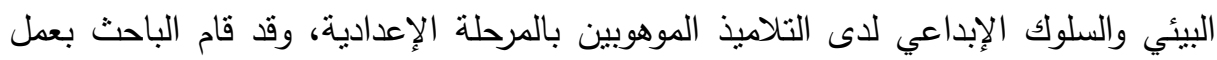

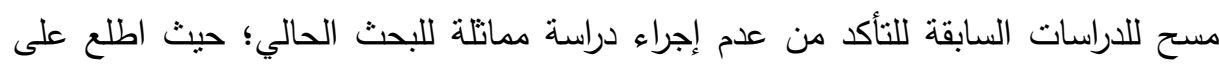
المواقع البحثية المتخصصة مثل بنك المعرفة المصري، وتردد على المكتبات المركزية

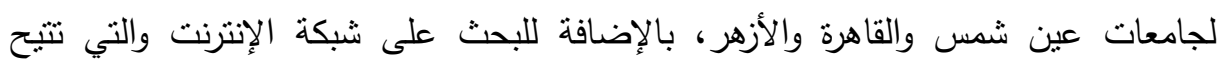
عناوين البحوث والدراسات من مختلف الدول وتوفر النص الكامل لها أو توفر ملخصاتها على الإنى

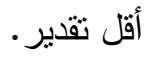
أهمية الموضوع الذي تبحثه والمتغيرات التي تتناولها؛ حيث تتناول تقويم دور مراكز

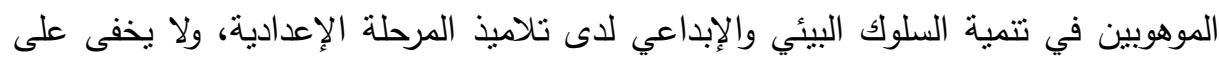

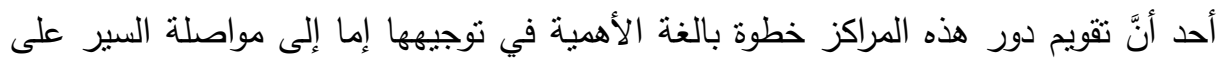
نفس المنوال أو إجراء ما يلزم من التعديلات اللازمة لتطوير أدائها وزيادة فعاليتها.

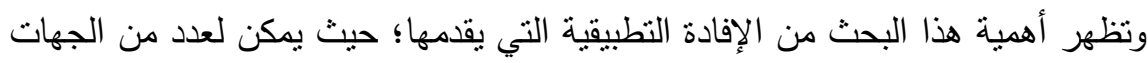

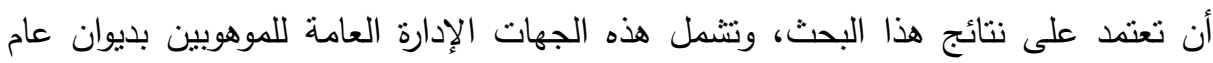

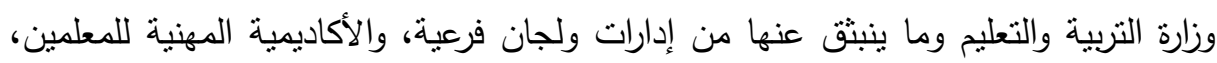
ومركز تطوير المناهج، والمركز القومي للامتحانات والنقويم التربوي.

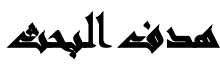

تثتَّل هدف البحث الحالي في تقويم دور مراكز الموهوبين بمديرية التربية والتعليم بالقاهرة

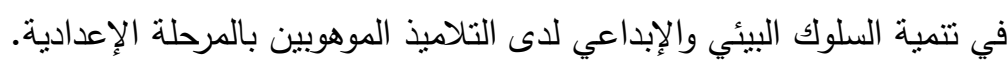

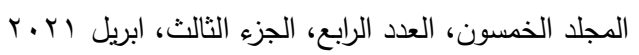

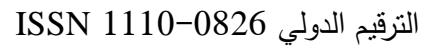




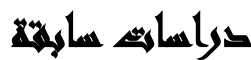

أولًا: دراسات وبحوث سابقة حول المؤسسات المعنية برعاية الموهوبين والمتفوقين:

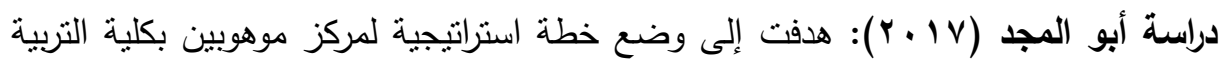

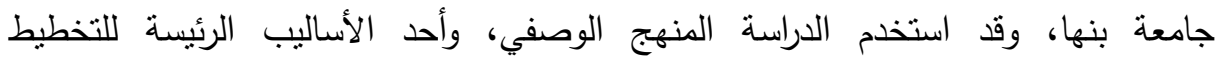
الاستراتيجي وهو أسلوب التحليل البيئي SWOT Analysis، وتمنلت أهم نتائج البحث في لهابه حاجة كلية التربية لمركز موهوبين، كذلك وضع تصور عام لخطة استراتيجية يمكن أن تساعد

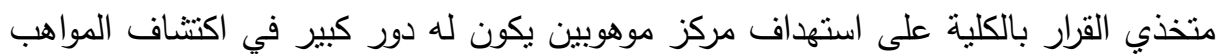
من طلبة مراحل التعليم قبل الجامعي.

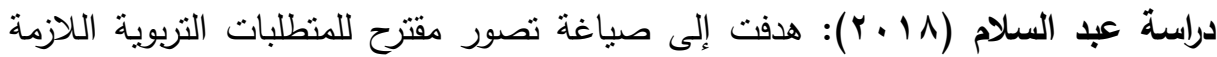

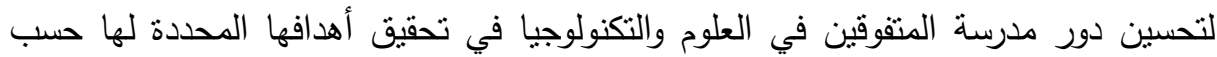

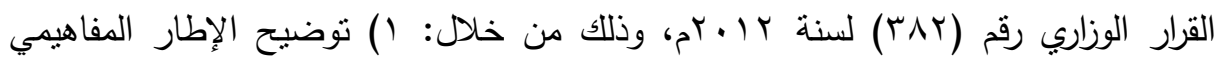

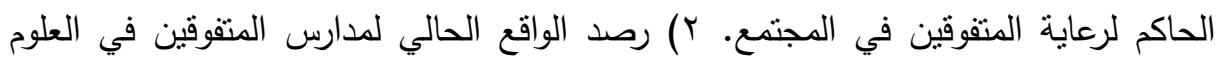

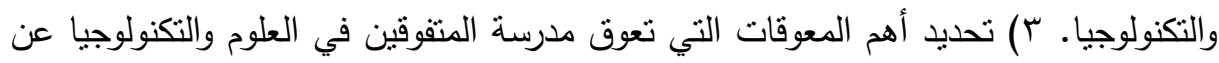
تحقيق أهدافها. ؟) تحديد المتطلبات التربوية اللازمة لتفعيل دور مدرسة المتفوقين في العلوم

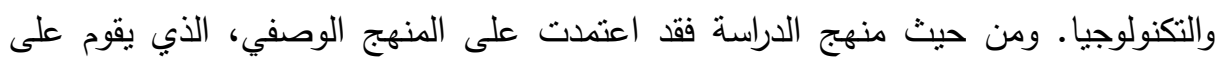
وصف الظاهرة وتحليلها تحليلًا يغلب عليه طابع الرصد وتنجيل الواقع وتحليل البيانات

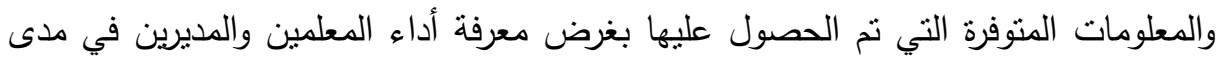
تحقيق الصبغة العالمية والابتكارية في مدارس المتفوقين في العلوم والرياضيات. ومن حيث نتائج الدراسة فقد توصلت إلى أن المعوقات التي تعوق مدرسة المتقوقين في العلوم والتكنولوجيا عن تحقيق أهدافها تتمثل في: ( ) صعوبة التتسيق بين المدارس والإدارات والوزارة وأولياء الأمور عند وضع البرامج الخاصة برعاية المتقوقين، ب إنلة تقهم المحيطين بالمتفوقين

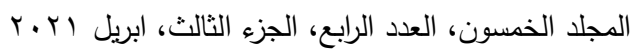

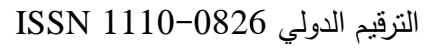


لدوافعهم واحتياجاتهم، ؟) صعوبة مناسبة إمكانية المدارس العادية لقدرات المتفوقين سواءً على (صلى

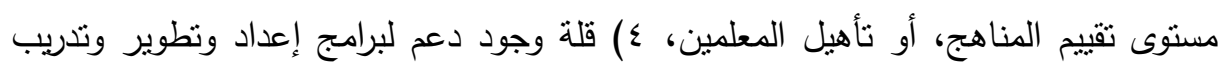

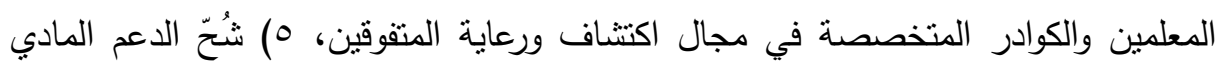

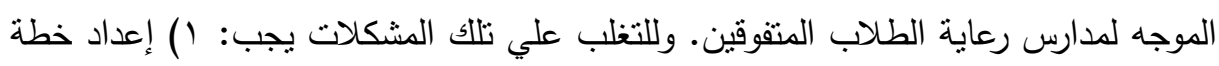
عامة للكثف عن الطلاب المتفوقين في المدرسة، rابل توجيه الطلاب المتفوقين لممارسة

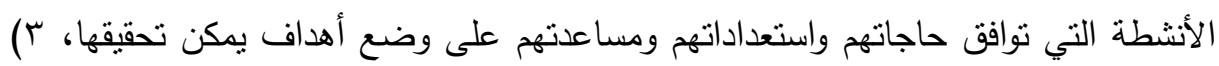

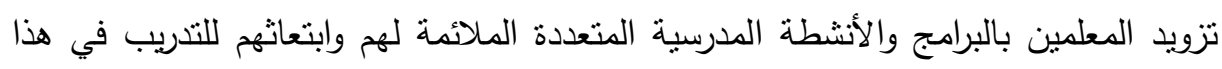

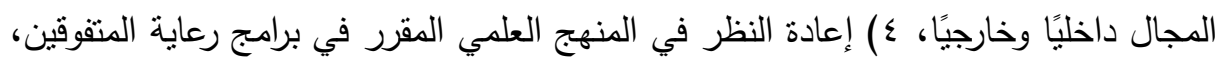

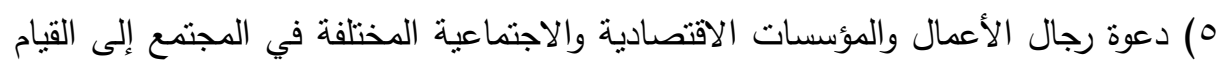
بدور إيجابي لرعاية الطلاب المتفوقين ودعم الأنشطة المحققة لذلك.

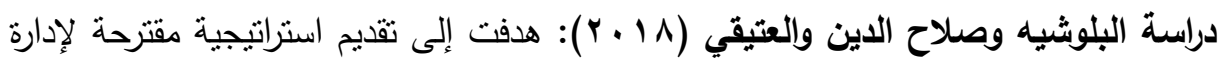

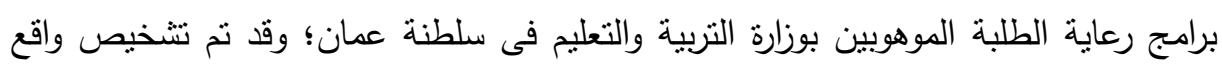

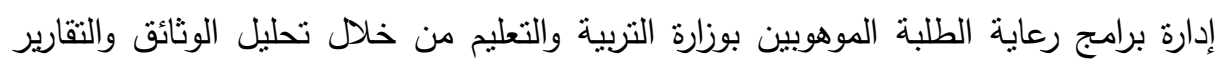
الرسمية والقرارات الوزارية فى هذا المجال، واعتمدت الدراسة على أسلوب التحليل البيئي الرباعي SWOT Analysis؛ حيث نم تطبيق استمارة على مجموعة من الخبراء فى مجال

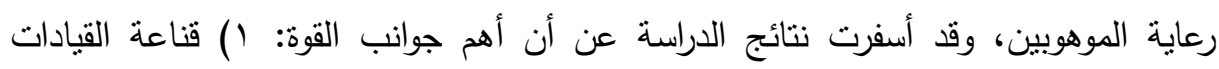

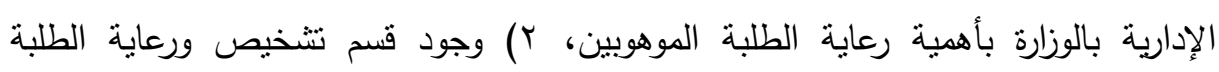

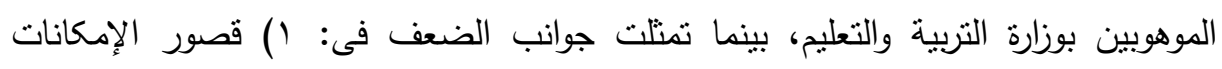

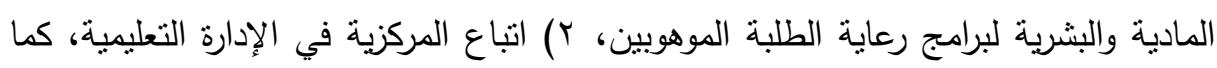

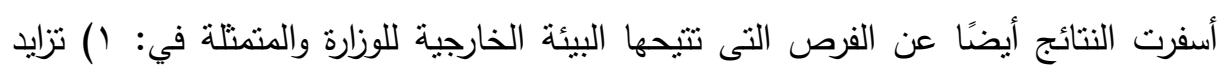

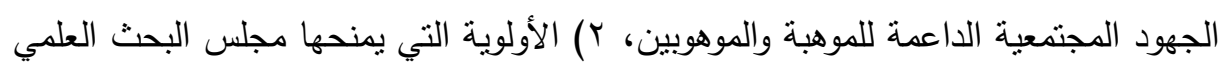

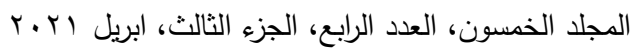

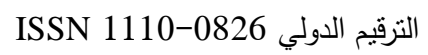


لرعاية الموهوبين، بينما تمثلت أبرز التهديدات في: () الافتقار إلى تخصصات أكاديمية في مجال الموهبة بمؤسسات التعليم العالي، r) قلة الوعي المجتمعي بأهمية الطلبة الموهوبين واحتياجاتهم. تانيًا: دراسات وبحوثئاتهم سابقة حول السلوك البيئي:

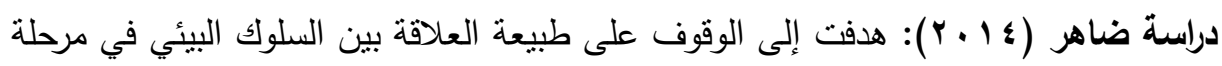
المراهقة بالعجز المتعلم واختبار مهنة المستقبل لدى عينة من الطلبة في محافظة دمثق.

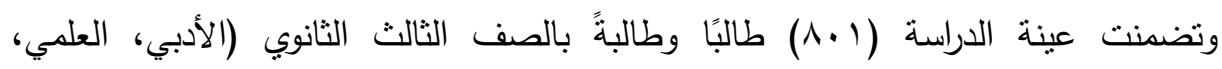
التجاري، الصناعي). واشتنملت أدوات الدراسة على ثلاثة مقاييس: (العجز المتعلم، السلوك

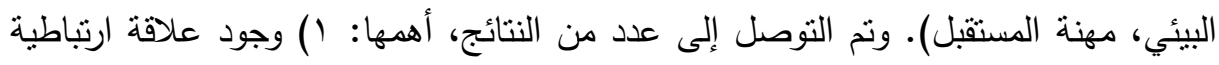

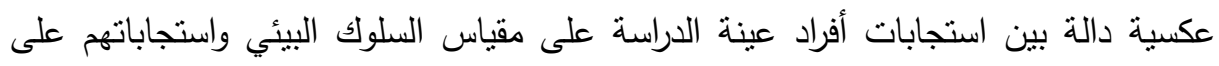

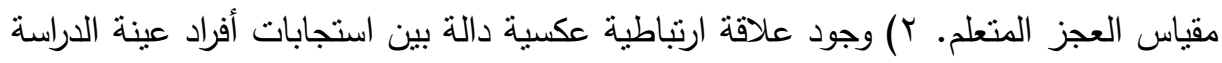
على مقياس العجز المتعلم واستجاباتهز على مقياس مهنة المستقبل. rا) وجود علاقة ارتباطية

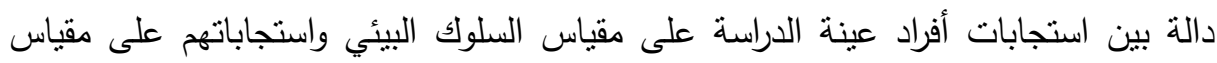

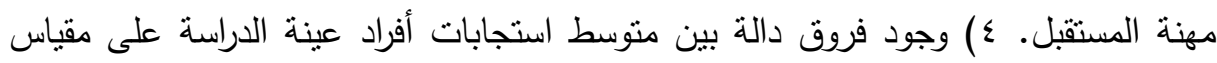

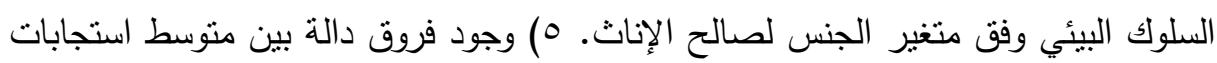

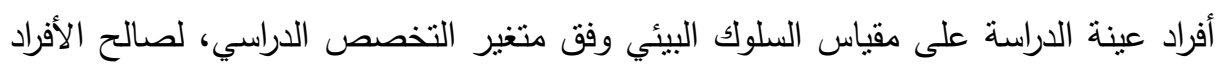

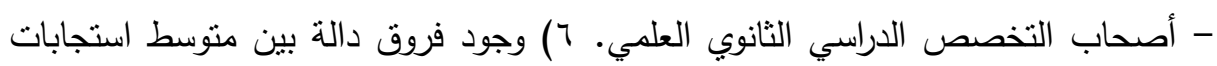

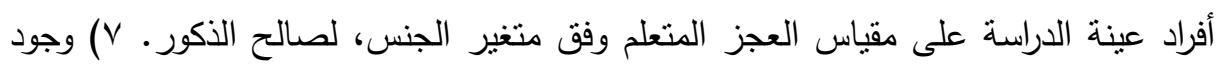
فروق دالة بين منوسط استجابات أفراد عينة الدراسة على مقياس العجز المتعلم وفق متغير

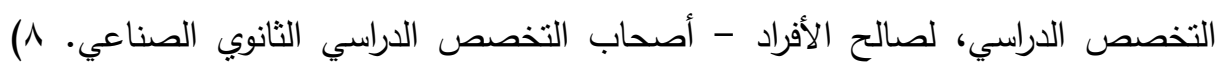

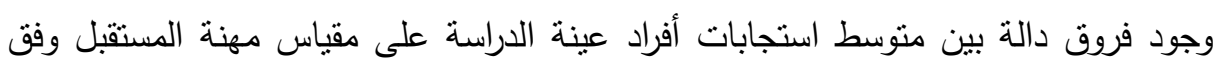

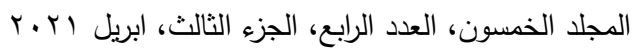

$$
\begin{aligned}
& \text { الترقيم الدولي 0826-0 ISSN 1110 }
\end{aligned}
$$


متغير الجنس، لصالح الإناث. 9) وجود فروق دالة بين متوسط استجابات أفراد عينة الدراسة

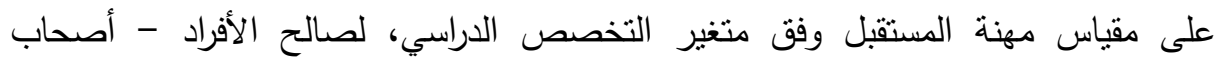
التخصص الدراسي الثانوي في جميع الاختصاصات، وليست دالة فيما بينها، وبالتالي تكون أقل نسبة متوسطة نحو مهنة المستقبل هم طلبة الثانوي الصناعي.

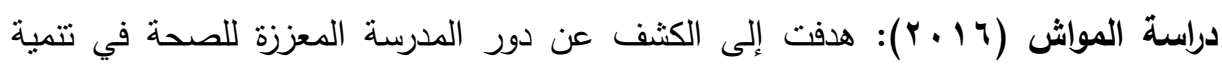

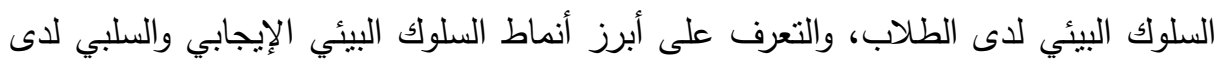

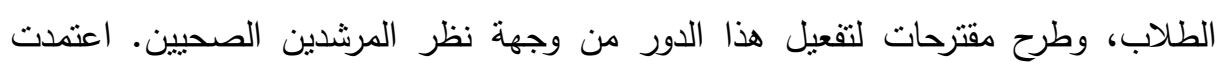

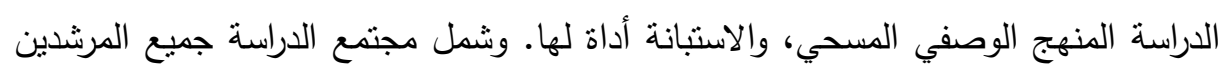
الصحيين في المدارس الحكومية النهارية بنين بمدينة الرياض المطبقة لبرنامج المدارس لوسئه

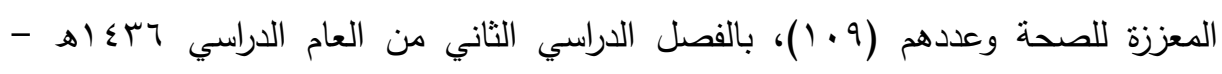

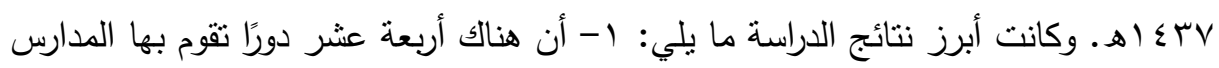

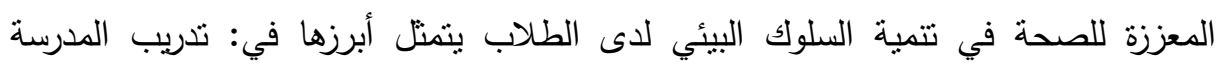

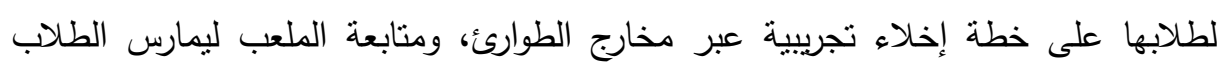
النشاط الرياضي بأمان، وتزويد العيادة المدرسية بالأدوات اللازمة للإسعافات الأولية، وإجراء ولئاء

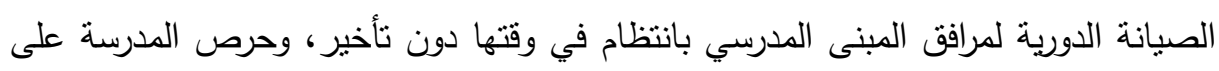

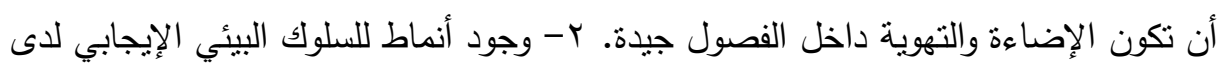

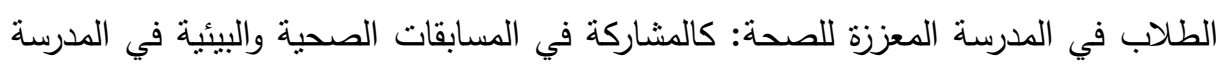
بعدد مناسب، والمحافظة على نظافة ملابسهم، والمشاركة في نظافة المدرسة وتجميل

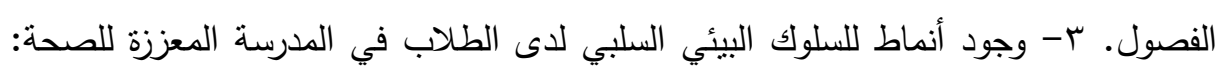
كالإسراف في استخدام المياه أثناء الوضوء وغسل اليدين، وضعف مشاركة الطلاب في خدمة لئل

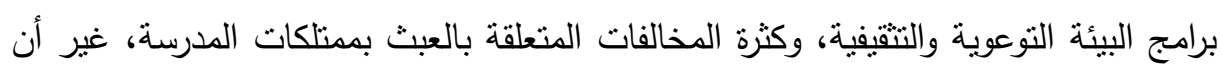

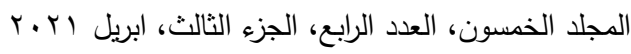

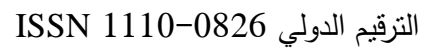


أفراد عينة الدراسة غير موافقين على وجود نمط واحد من أنماط السلوك البيئي وهو : "لا يتبع

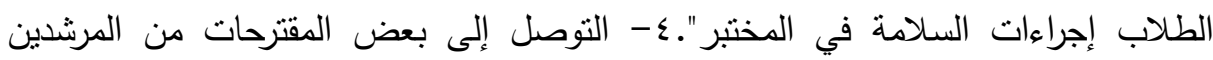

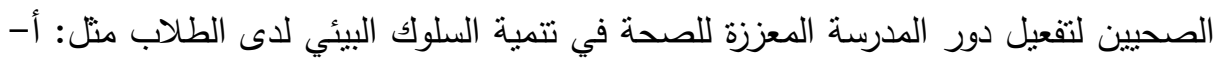

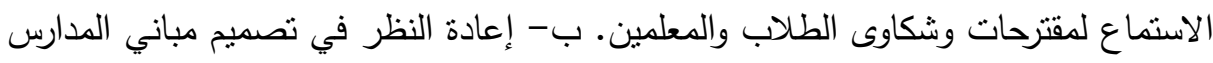

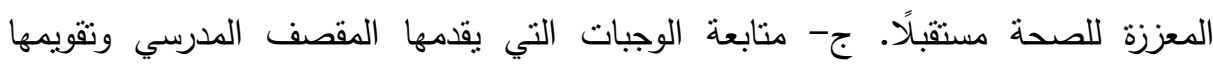
باستمرار • د- تأهيل المرشد الصحي لإلقاء محاضرات على المعلمين وأولياء أمور الطلاب.

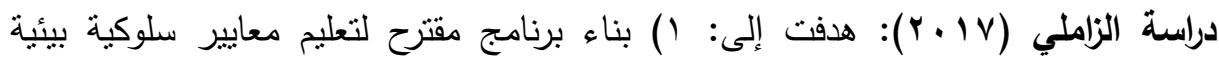

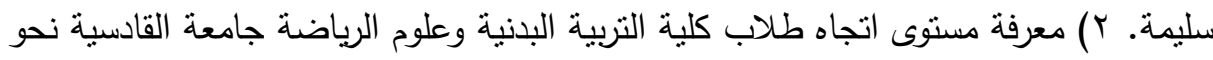
البيئة السليمة. r) معرفة أثر البرنامج المقترح على تعديل اتجاهات طلاب كلية التربية

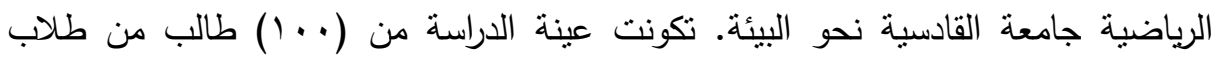

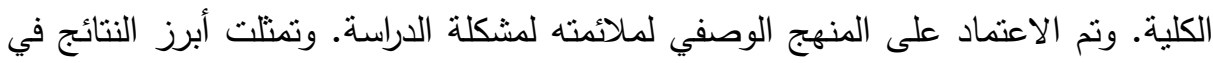
أن سلوك طلاب كلية التربية الرياضية جامعة القادية نحو البيئة بدأ يتغير نحو فهم أثر لثرئية

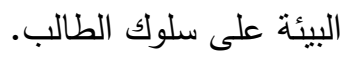
ثالثًا: دراسات وبحوث سابقة حول الموهبة والتفوق والإبداع:

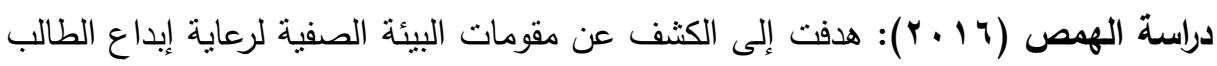
الفلسطيني في المرحلة الثانوية بالمدارس الحكومية، واستخدمت الدراسة المنهج الوصفي التحليلي، كما استخدمت الدراسة أداة استبانة للإجابة عن أسئلة الدراسة، على عينة مقدارها

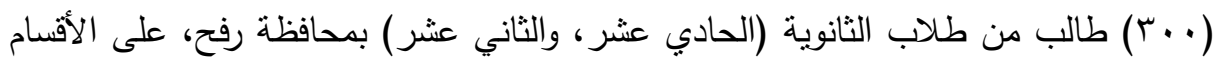

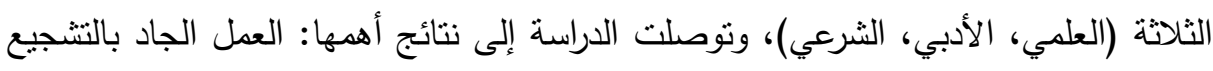

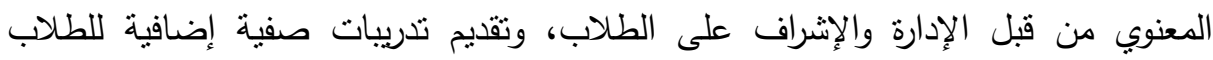
المتفوقين من الكتاب المدرسي وغيره، وكذلك نتجيع الطلاب المبدعين للانتساب إلى "أسرة 
الإبداع" في المدرسة، والعمل على تكليف هؤلاء الطلاب بمقررات دراسية غير منهجية عن بقية الطلاب، مع نوزيعهم بين أقرانهم في الصف المدرسي، مع توفير الحرية للطالب في هولاء التقكير والتعبير عن رأيه.

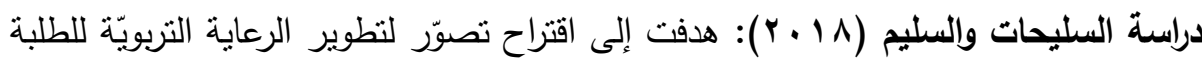

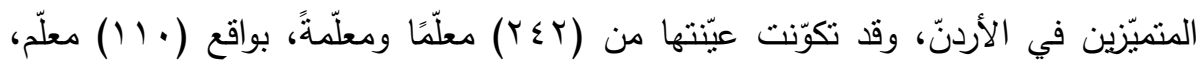

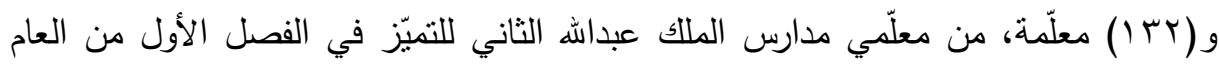

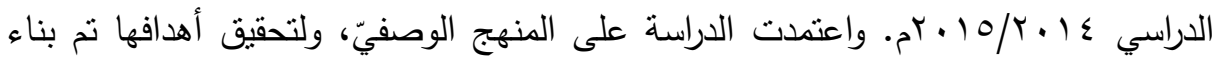
استبانة للكثف عن واقع الرعاية التربويّة للطلبة المتميّزين في الأردنّ وتم التحقق من معاملات ولته

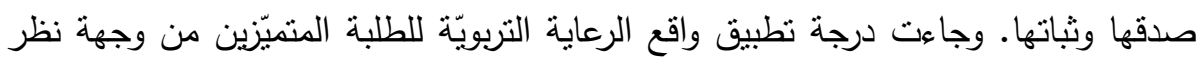

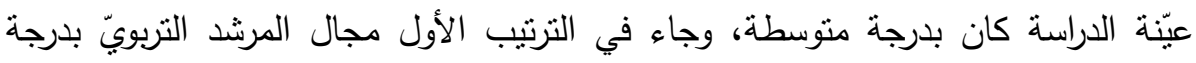

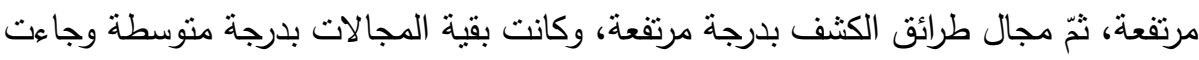

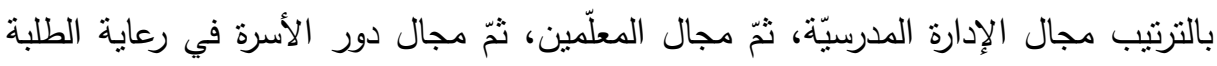

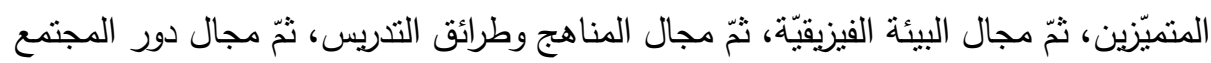

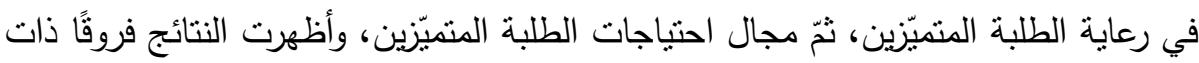

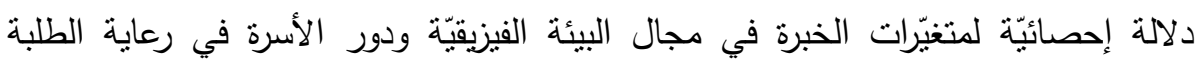

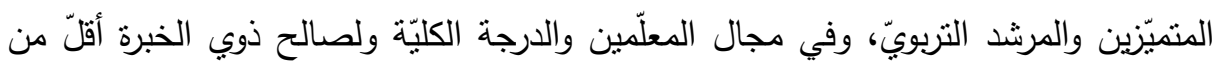

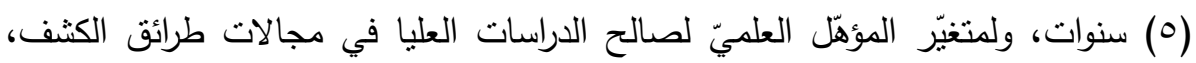

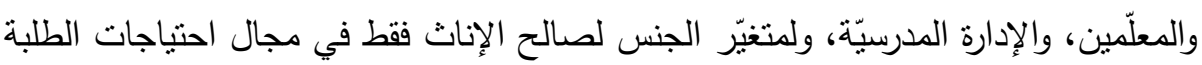

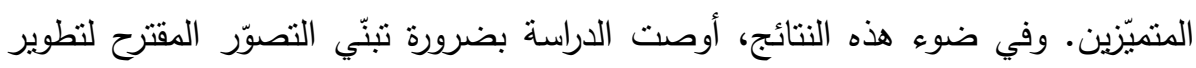

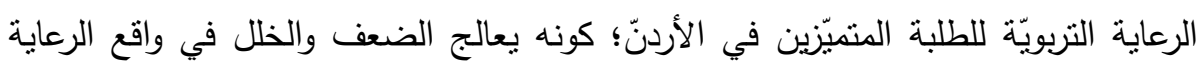
التربيّة للطلبة المتميّزين من وجهة نظر عيّنة الدراسة.

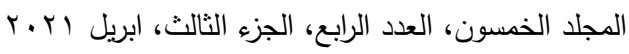

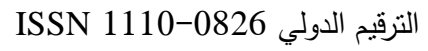


دراسة عشرية (9 (ب): هدفت إلى تقييم برنامج النخبة في رياض الأطفال في السودان

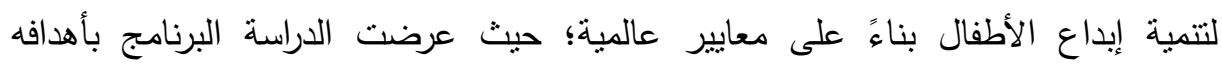
والاستراتيجيات المنبعة، ثم قارنت مخرجات رياض الأطفال التي طبقت البرنامج وفق المعايير

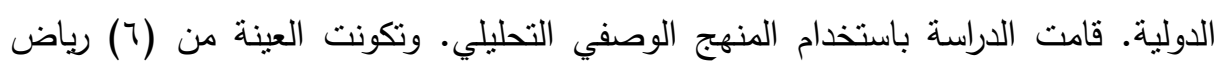

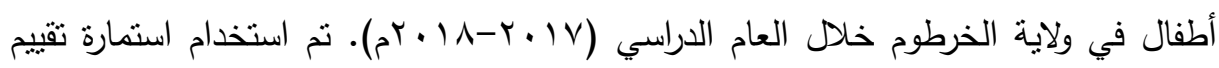

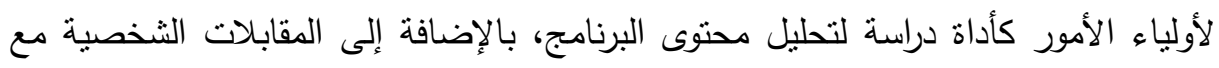
الإداريين والمعلمين. بعد التحقق من ثبات الأدوات وصحتها، نم تحليل البيانات باستخدام

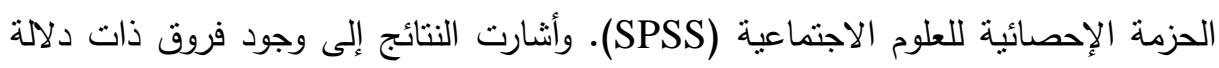

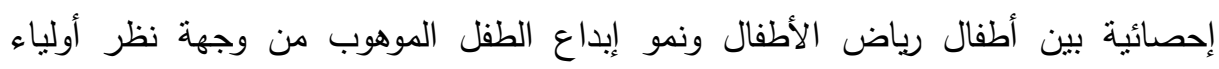
الأمور، ووجود فروق ذات دلالة إحصائية بين أولياء أمور رياض الأطفال وتتمية إبداع الطفل

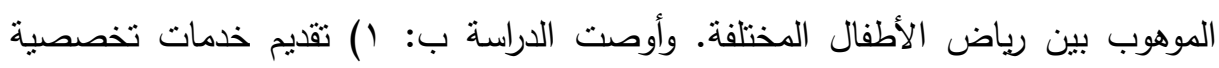
للأطفال ذوبي القدرات العالية، r) القيام بإجراء مزيد من الدراسات حول هؤلاء الأطفال.

\section{تعليق عام على الدراسات والبحوث السابقة:}

• ت توعت أهداف الدراسات والبحوث السابقة مما يدل على أهمية المتغيرات المدروسة وقيمة

$$
\text { هذا الموضوع وأهميته. }
$$

• حداثة هذه الدراسات والبحوث؛ حيث امتد المدى الزمني لها في نطاق السنوات العشر

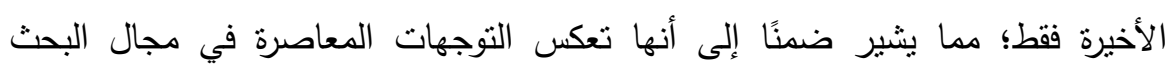
العلمي التربوي فيما يتعلق بالمراكز والمؤسسات المعنية برعاية وخدمة التلاميذ الموهوبين.

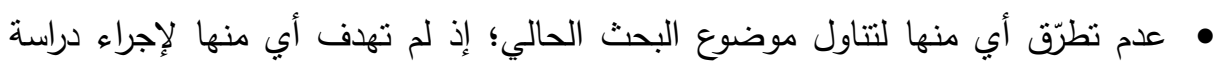

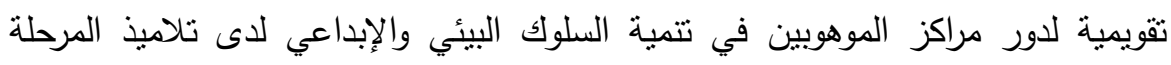
الإعدادية المترددين عليها بمصر عمومًا ومحافظة القاهرة خصوصيًا. 
• تتوعت مناهج البحث المستخدمة في هذه الدراسات والبحوث، فقد اعتمدت بعض الدراسات على المنهج الوصفي في حين لجأت دراسات أخرى للمنهج التجريبي.

\section{الإطار النظليه اللهمبه}

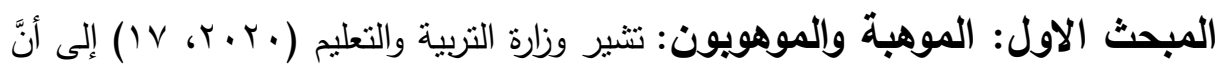

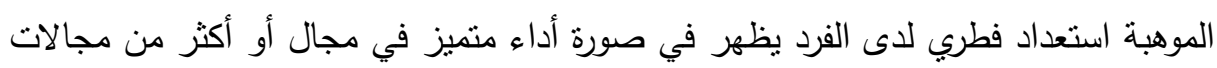

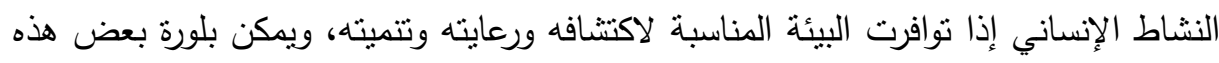

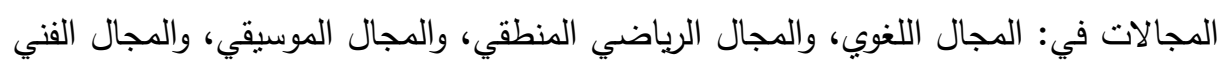

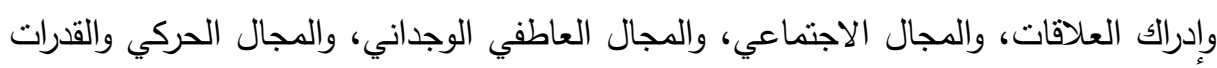
الجسمية".

وتعد عملية الكثف عن التلاميذ الموهوبين والمتفوقين أحد أهم مدخلات برامج رعاية

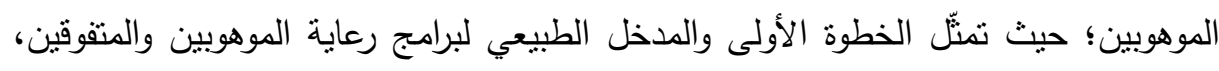

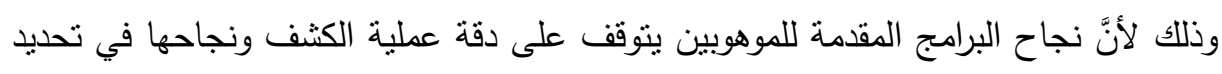

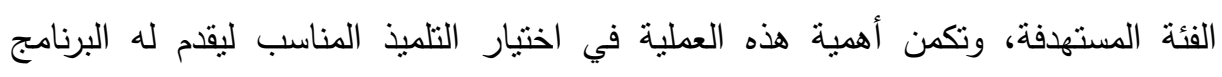

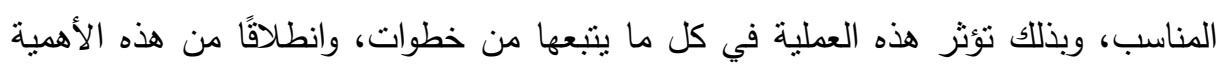

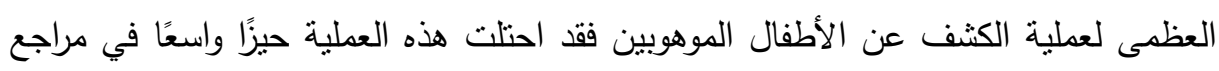
تربية الموهوبين والمتفوقين، كما خصصت لها فصول كاملة في مراجع علم نفس الموهبة

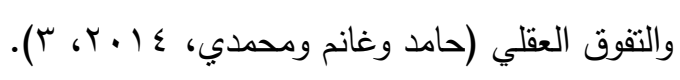

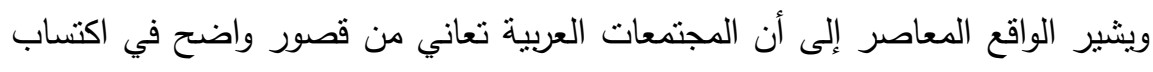

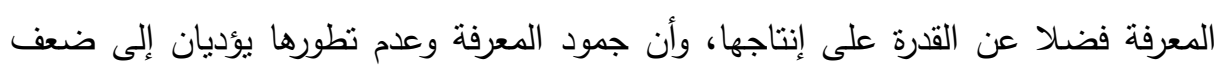

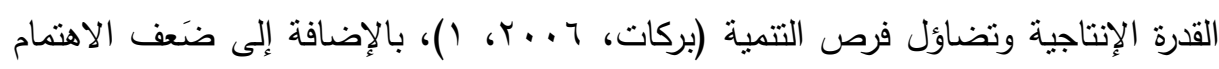

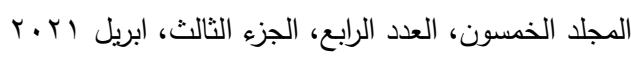

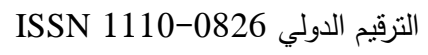


بالموهوبين؛ مما ترثَّب عليه هجرة أصحاب المواهب إلى البلدان التي ترعى تلك العقول فيما

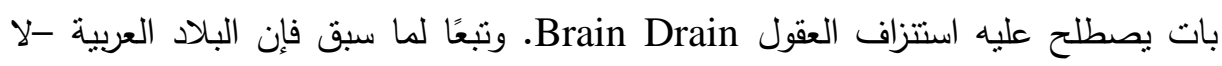
سيما مصر - نواجه تحديًا يستوجب مضاعفة الجهود المبذولة للاهتمام بالموهوبين وتقويم

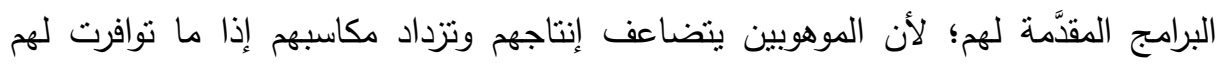

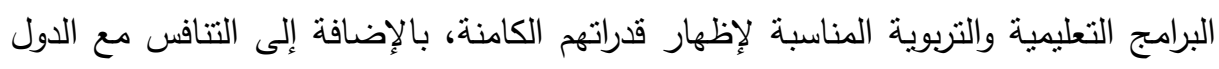
الأخرى؛ فالموهوبون من أغلى الكنوز وأنفسها التي تتتافس عليها شعوب العالم، وتعتدد عليها لإنها الدول في حاضرها ومستقبلها، فَهُم القوة الحقيقية لأي مجتمع يريد التقدم والازدهار (كزمان، . ( T r. . . O

ويرى الباحثنون الحاليّون أنَّ مراكز رعاية الموهوبين تحمل على عاتقها مهمة تعميق وعي

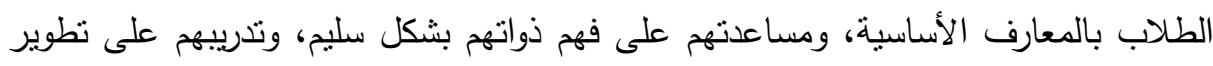

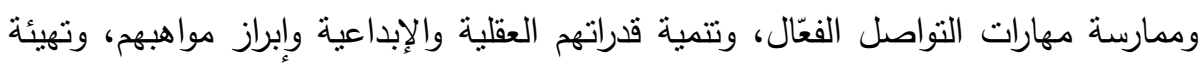

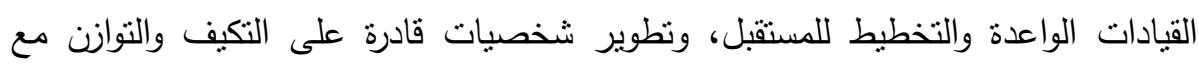
مستجدات ومستحدثات العصر • وتقوم فكرة هذه المراكز على أساس عدم الفصل بين الطلاب الموهوبين أو المتفوقين وزملائهر من الطلاب العاديين في المدرسة، وإنما ينم تقديم الرعاية

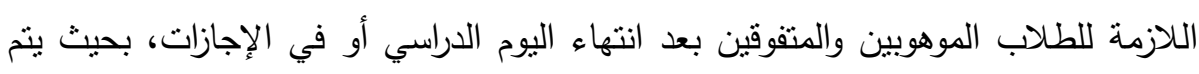
تقديم البرامج الإثرائية لهم في المجالات التي يبرزون تفوقهم فيها، وذللك من خلال البهن البرامج

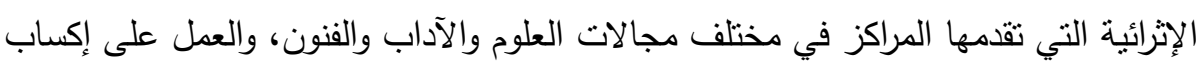

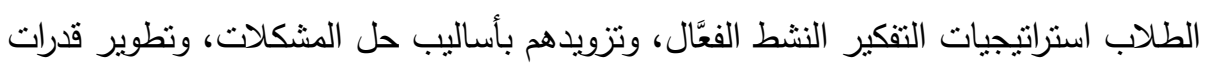
الابتكار لدى الطلبة الموهوبين، وإكسابهم المهارات الثخصية ومهارات البحث العلمي.

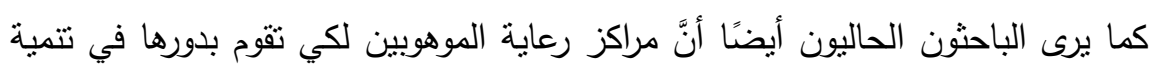

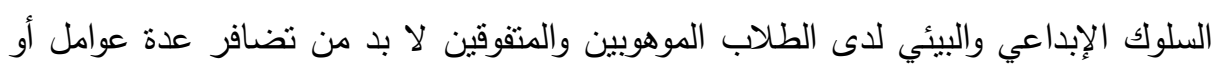


عناصر تسهم في إنجاح جهود هذه المراكز، وتشمل هذه المرتكزات أربعة محاور هي: () )

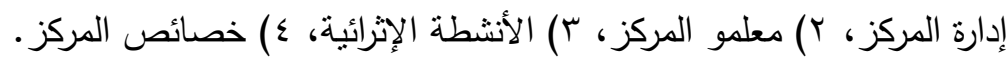
المبحث الثاني: السلوك البيئي: يشير مفهوم السلوك البيئي إلى كل ما بصدر من الفرد من أفعال وتصرفات وممارسات، ظاهرة كانت أم باطنة، عقلية معرفية، مزاجية انفعالية، نفسية

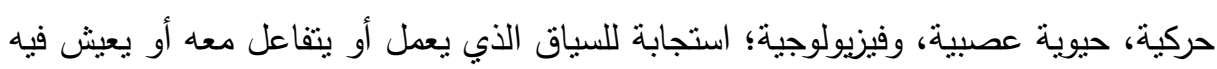

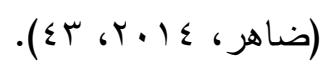

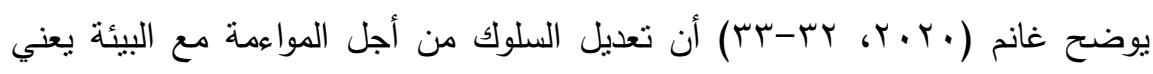
جعله موائمًا ومنوافقًا مع متغيرات ومثيرات البيئة، وتوجد العديد من الاستراتيجيات والفنيات التي تستخدم في تعديل السلوك مثل: ( ) استخدام المدعمات الإيجابية بهدف تحسين البيئة

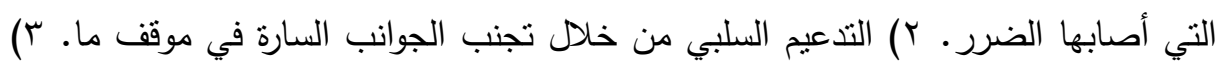

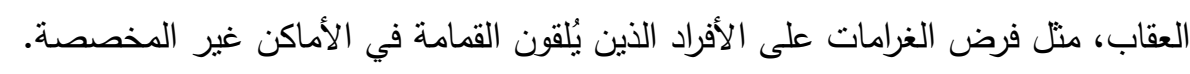

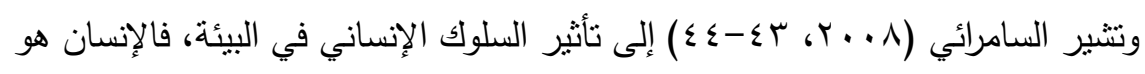
الأساس في التفاعل مع البيئة، وسلوكه هو الدحدد لنوع الأثر الذي ينركه على البيئة، وينقسم الإنى

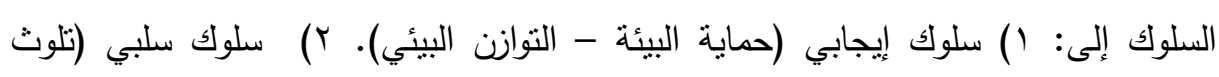
البيئة). ويرى الباحثون الحاليون أنَّ التلاميذ الموهوبين والمتقوقين والمبدعين باعتبارهم نماذج

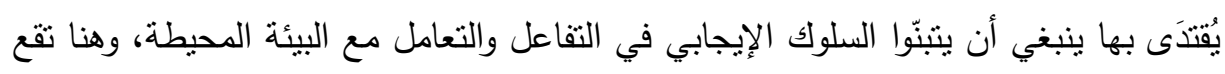
على عاتق مركز رعاية الموهوبين مسئولية حث وتشجيع التلاميذ على تبني السلوك البيئي الملائم، وإنشعارهم بقيمة ذلك، وكيف أنَّ تنبّهمه لمثل هذه الأنماط الإيجابية من لسلوك البيائي

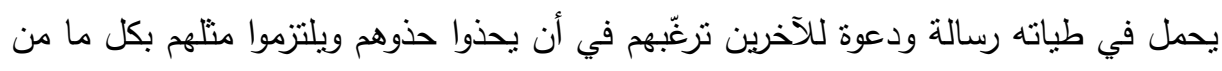
شأنه حماية البيئة والمحافظة عليها.

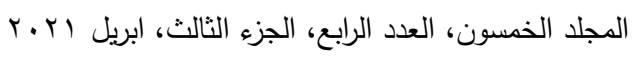

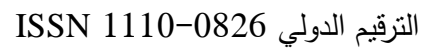


كما يرى الباحثثن الحاليون أنَّ التلاميذ الموهوبين والمتفوقين والمبدعين يمكنهم الإسهام في نشر الوعي البيئي وتثقيف أفراد المجتمع بالسلوك البيئي الإيجابي، فالتلميذ الموهوب في

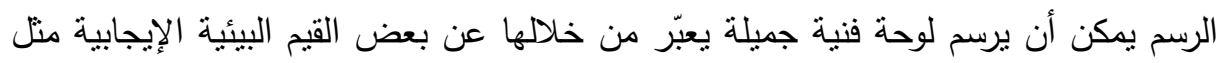

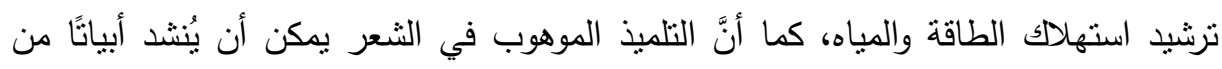

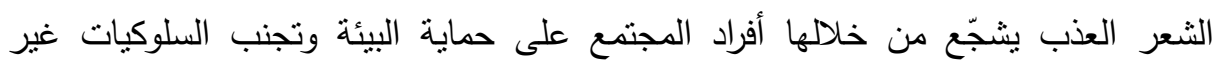
الملائمة التي تضر بها، وكذلك يمكن للتلميذ الموهوب في التمثيل أن يصوّر مقاطع تمثيلية لتحقيق الهدف نفسه؛ وبالتالي ينت توظيف واستثمار مواهب وطاقات التلاميذ الموهوبين ومهاراتهم في خدمة البيئة. المبحث الثالث: السلوك الإبداعي: يتركز مفهوم الإبداع عادة على سمات الثخص

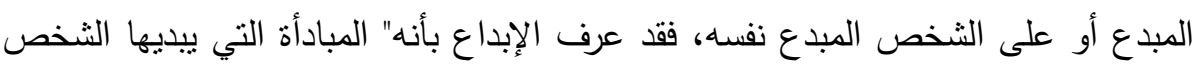

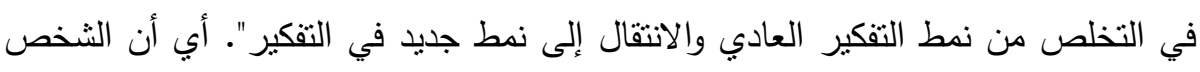
المبدع هو الشخص الذي يبحث ويستقصي ويكتثف ويؤلف، ومن السمات التي لها علاقة

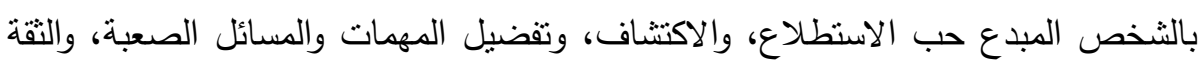

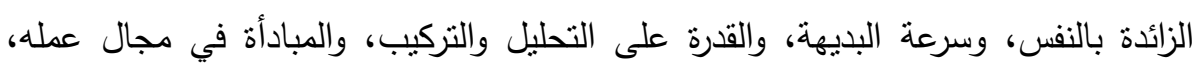

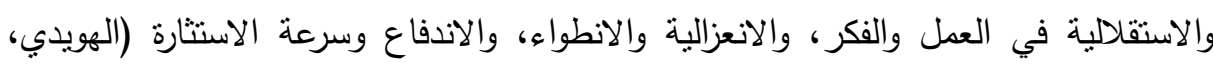

$$
\text { . r r r. L }
$$

ويرى الباحثون الحاليون أنَّ الأثخاص المحيطين بالتتلاميذ الموهوبين والمتفوقين

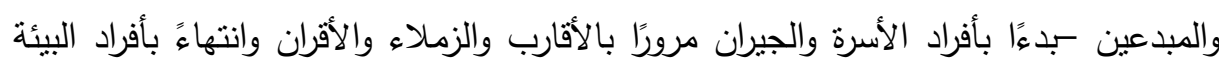

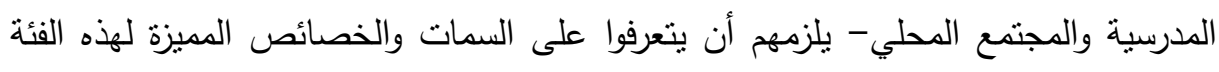

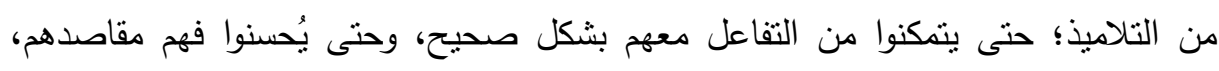

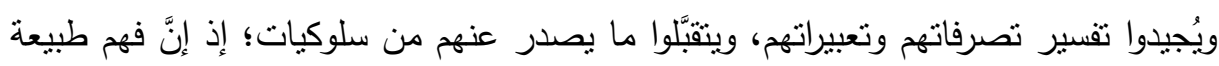

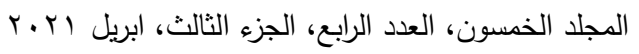

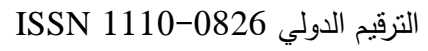


شخصياتهم وإدراك سماتهم وخصائصهم قادر على تحسين العلاقات والتفاعلات الاجتماعية

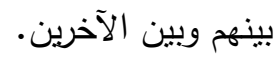

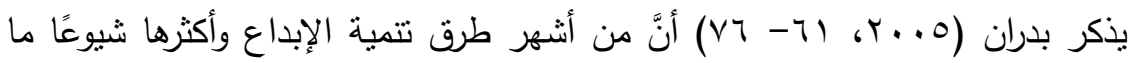
يلي: () طريقة العصف الذهني، وطريقة القبعات الست، وطريقة الثخصيات الأربعة، وطريقة الاسترخاء الذهني والبدني، وطريقة التركيز العقلي، وطريقة الأسئلة الذكية. منهجية البحث والأداة المستخدمة: اعتد البحث على المنهج الوصفي من خلاد تطبيق استبانة تقويم دور مراكز الموهوبين في تتمية السلوك البيئي والإبداعي لدى تلاميذ

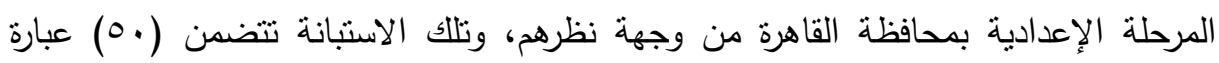

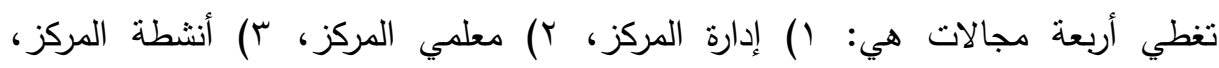

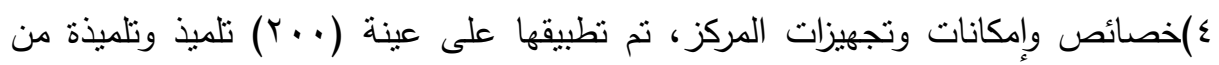

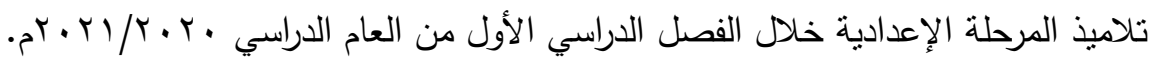
تم التحقق من الخصائص السيكومترية للاستبانة المستخدمة في البحث الحالي من خلال:

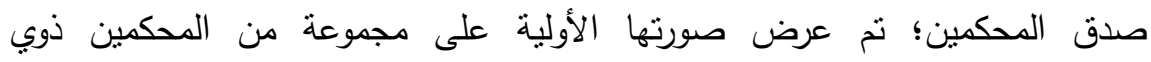
الاختصاص والخبرة من أعضاء هيئات التدريس بعدد من الجامعات، وبناءً على آراء السادة

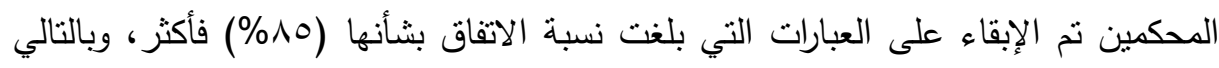

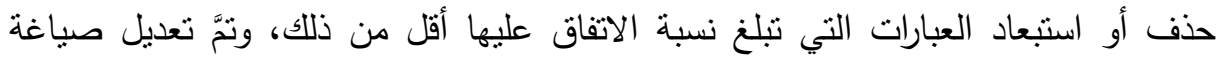
بعض العبارات.

حساب الاتساق الداخلي لأداة البحث؛ حيث قام الباحثون بحساب الاتساق الداخلي

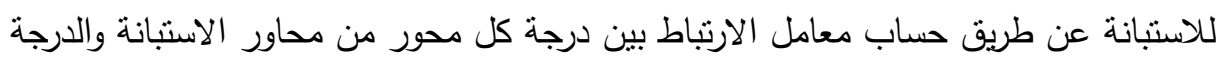

الكلية للاستبانة كما يتضح من جدول (1).

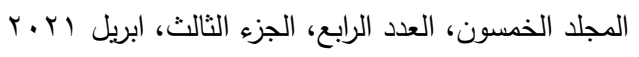

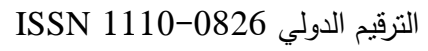


مجلة العلوم البيئية

معهد الدراسات والبحوث البيئية - جامعة عين شمس لئه

محمد عبد التواب عبد المولى وآخرون

جدول (1): يوضح معامل ارتباط بيرسون بين محاور الاستبانة والمجموع الكلي لها

\begin{tabular}{|c|c|c|}
\hline الجذر التربيعي لمعامل الارتباط & معامل الارتباط & المحور \\
\hline ( & $* * .6 \vee 90$ & المحور الأول \\
\hline .6711 & $* *$. ‘VAr & المحور الثاني \\
\hline. . Vᄉ & 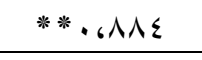 & المحور الثالث \\
\hline $.6 \vee 01$ & 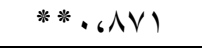 & المحور الرابع \\
\hline
\end{tabular}

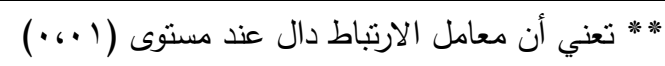

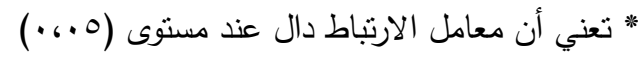

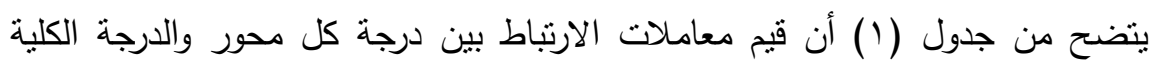

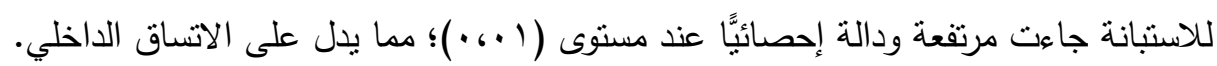
ثبات أداة البحث؛ حيث ثام الباحث بحساب ثثات الاستبانة باستخدام معامل ألفا

كرونباخ، ويوضح جدول (Y) قيمة معامل ألفا كرونباخ لمحاور الاستبانة والدرجة الكلية. جدول (ץ): يوضح معامل ثبات ألفا كرونباخ لمحاور الاستبانة والدرجة الكلية

\begin{tabular}{|c|c|c|}
\hline معامل الثبات & عدد العبارات & الاستبانة \\
\hline $.6 V V T$ & $\pi$ & المحور الأول \\
\hline. . VAV & ir & المحور الثاني \\
\hline . 6Аrq & 11 & المحور الثالث \\
\hline .6199 & $1 \leqslant$ & المحور الرابع \\
\hline . & 0. & المجموع الكلي \\
\hline
\end{tabular}

يتضح من جدول (Y) أن قيم معاملات الثبات لهحاور الاستبانة تراوحت بين (مVT)، .-

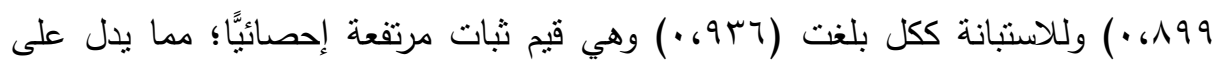
ثبات الاسنبانة؛ وبالتالي يشير إلى الثقة في النتائج التي يمكن التوصل إليها من تطبيقها. وصف عينة البحث: اثنتملت عينة البحث الحالي على كلا الجنسين (ذكور، إناث) ويوضح جدول (r) توزيع عينة البحث تبعًا لمتغير النوع (ذكور ، إناث) 
مجلة العلوم البيئية

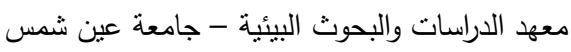

محمد عبد التواب عبد المولى وآخرون

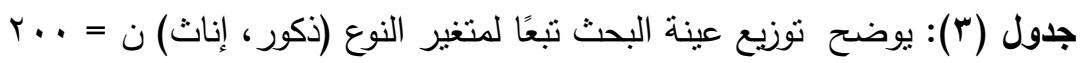

\begin{tabular}{|c|c|c|}
\hline النسبة المئوية & العدد & النوع \\
\hline$\% \varepsilon \cdot .0$ & N1 & ذكور \\
\hline$\% 09.0$ & 119 & إناث \\
\hline$\% 1 \ldots$ & r.. & المجموع الكلى للعينة \\
\hline
\end{tabular}

كما تم سحب هذه العينة من (9) إدارات تعليمية تتبع مديرية التربية والتعليم بمحافظة

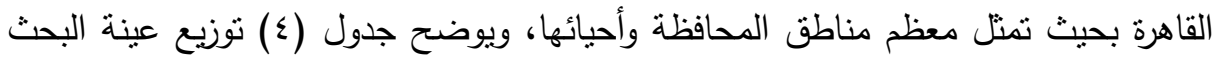

تبعًا لمتغير الإدارة التعليمية

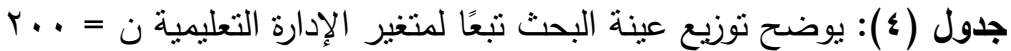

\begin{tabular}{|c|c|c|}
\hline النسبة المئوية & العدد & الإدارة التعليمية \\
\hline$\% \vee_{6} 0$ & 10 & إدارة المرج التعليمية \\
\hline$\% \backslash$ Y.o & ro & إدارة شبرا التعليمية \\
\hline$\% \backslash \wedge_{6}$. & 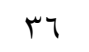 & إدارة الثرابية التعليمية \\
\hline$\% 1 \cdot$. & $r$. & إدارة السبتية التعليمية \\
\hline$\% \vee_{6} 0$ & 10 & إدارة القاهرة الجديدة التعليمية \\
\hline$\% \backslash Y_{6}$. & $r \leq$ & إدارة غرب القاهرة التعليمية \\
\hline$\% \backslash r_{6} 0$ & ro & إدارة الوايلي التعليمية \\
\hline$\% 9,0$ & 19 & إدارة الزاوية التعليمية \\
\hline$\% 1 \cdot .0$ & YI & إدارة شرق مدينة نصر التعليمية \\
\hline$\% 1 \ldots$ & $r \ldots$ & المجموع الكلي للعينة \\
\hline
\end{tabular}

كما اشتملت عينة البحث الحالي على التلاميذ الموهوبين في مجالات متتوعة بلغت

(r) (1) مجالًا للموهبة، ويوضح جدول (0) توزيع عينة البحث تبعًا لمتغير الموهبة أو مجال

التميُّز

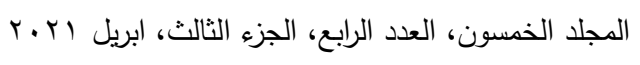

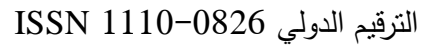


مجلة العلوم البيئية

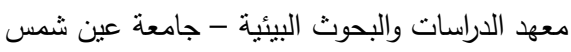

محمد عبد التواب عبد المولى وآخرون

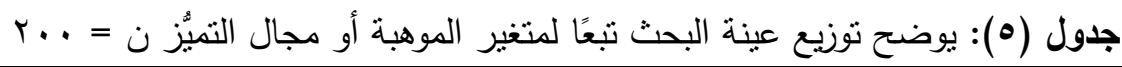

\begin{tabular}{|c|c|c|}
\hline النسبة المئوية & العدد & الموهبة أو مجال التميُز \\
\hline$\%) \leqslant 60$ & rq & 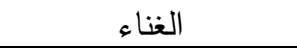 \\
\hline \% \% & $\varepsilon\rceil$ & 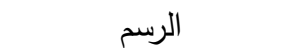 \\
\hline$\%$ & 71 & الأنشطة الرياضية \\
\hline$\% 0,0$ & 11 & الإلقاء \\
\hline$\% 7_{6} 0$ & 14 & 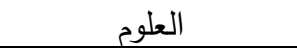 \\
\hline$\% 16$. & r & الثَِّّز \\
\hline$\% 0_{6}$. & 1. & العزف \\
\hline$\% 16$. & $r$ & الحاسب الآلي \\
\hline$\% \cdot 60$ & 1 & كتابة القصة \\
\hline$\% \wedge_{6}$. & 17 & التمثيل \\
\hline$\% 1,0$ & r & التصوير الفوتوغرافي \\
\hline$\% r_{6} 0$ & 0 & الاختراعات \\
\hline$\% \cdot .0$ & 1 & تلاوة وحفظ القرآن الكريم \\
\hline$\% 1 \ldots$ & $r \ldots$ & المجموع الكلي للعينة \\
\hline
\end{tabular}

ويمثّل التلاميذ المشاركون في البحث الحالي مختلف صفوف المرحلة الإعدادية (الأول،

والثاني، والثالث)، ويوضح جدول (7) توزيع عينة البحث تبعًا لمتغير الصف الدراسي.

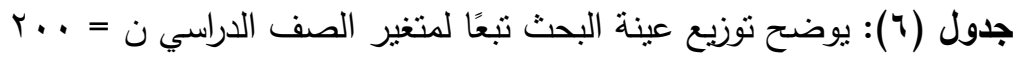

\begin{tabular}{|c|c|c|}
\hline النسبة المئوية & العدد & الصف الدراسي \\
\hline$\%$ rr.o & 70 & الأول الإعدادي \\
\hline$\% \leq .6$. & $\Lambda$. & الثاني الإعدادي \\
\hline \% YV.0 & 00 & الثالث الإعدادي \\
\hline$\% 1 \ldots$ & r.. & المجموع الكلي للعينة \\
\hline
\end{tabular}

186

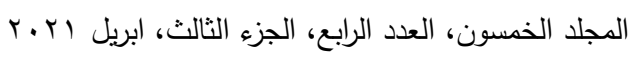

النزقيم الدولي 0826-0 1110 110 
مجلة العلوم البيئية

معهد الدراسات والبحوث البيئية - جامعة عين شمس لئ لمس

محمد عبد التواب عبد المولى وآخرون

\section{نمتائي الهمبه}

أ- النتائج الخاصة بترنيب محاور الاستبانة من حيث منوسط الأوزان النسبية لكل محور ودرجة توافره من وجهة نظر عينة البحث:

أوضحت نتائج التحليل الإحصائي لأداة البحث أن مجمل محاور الاستبانة ذات درجة

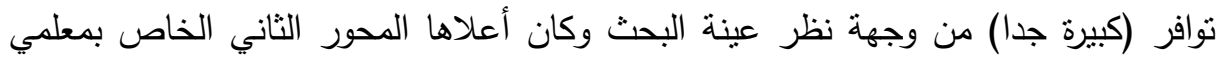

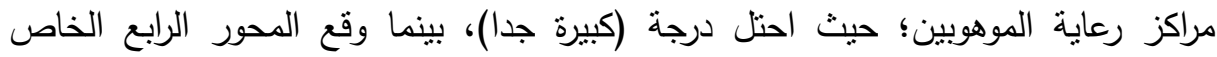
بخصائص وإمكانات وتجهيزات مراكز رعاية الموهوبين في المرنبة الأخيرة؛ حيث احتل فقط درجة (كبيرة)، كما جدول (V) يوضح استجابات أفراد العينة على المحاور مجملة: جدول (V): يوضح إجمالي استجابات عينة البحث على كل محور من محاور الاستبانة

\begin{tabular}{|c|c|c|c|c|c|c|}
\hline الترتيب & متوسط الأوزان النسبية & الانحراف & المتوسط الحسب & | العبارات & المحور & p \\
\hline r r & $\Gamma_{\text {r. }}$ & $06 \cdot r$ & E\{rI & 11 & الأول & 1 \\
\hline 1 & $\Gamma_{6} \varepsilon 7$ & $\varepsilon, 7 \varepsilon$ & $\varepsilon 1,04$ & ir & الثاني & $r$ \\
\hline r & T، & 0.19 & r.VA & 11 & الثالث & r \\
\hline$\varepsilon$ & r.r. & $\Lambda_{6} V V$ & $\varepsilon \varepsilon_{6} \wedge \wedge$ & $1 \varepsilon$ & الرابع & $\varepsilon$ \\
\hline مرتفعة جدًا & ס T. & 19617 & ITV، & 0. & مالي & \\
\hline
\end{tabular}

يتضح من جدول (V) أن الأوزان النسبية لمحاور الاستبانة تراوحت بين (•r،r) بالنسبة

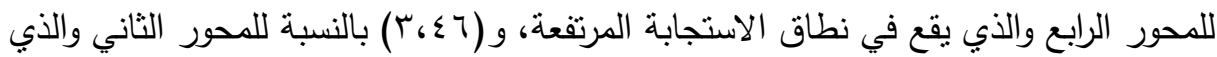
يقع في نطاق الاستجابة المرتقعة جدًا، وقد بلغ متوسط استجابات عينة الهابه الدراسة على على الاستبانة

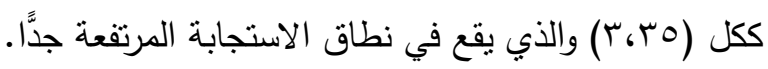


ويمكن تفسير كون المحور الثاني الخاص بمعلمي مراكز رعاية الموهوبين قد احتل

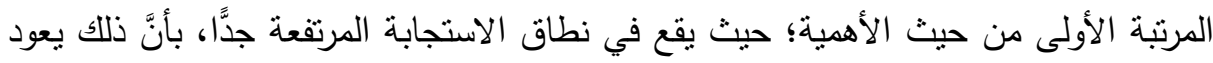
إلى الدور الفعَّل والمؤثر الذي يقوم به معلمو مراكز الموهوبين في التفاعل مع التلاميذ بشكل إيجابي يسهم في تتمية السلوك البيئي والسلوك الإبداعي لدى التلاميذ.

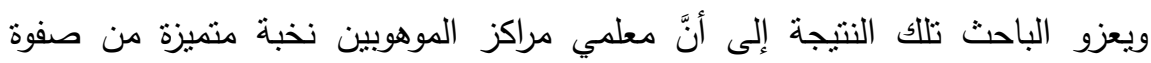

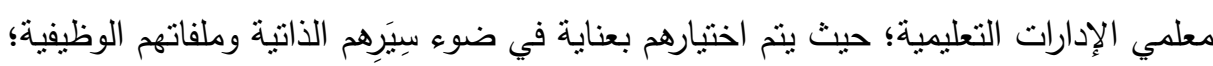

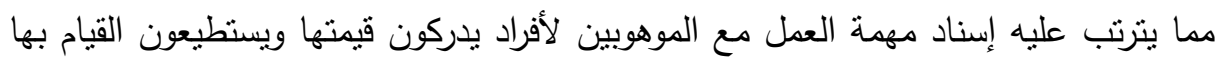

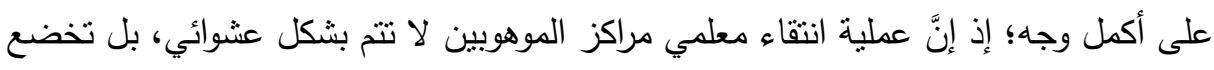
لأسس واضحة وقواعد منظمّة تأخذ بعين الاعتبار ما يتمتع به أولئك المعلمون من كفايات

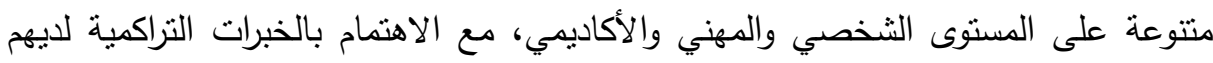
والتي ينوقَّع أن لها دور كبير في إثراء مهام عملهم مع التلاميذ الموهوبين.

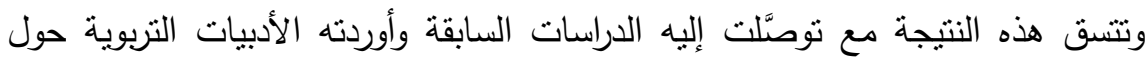

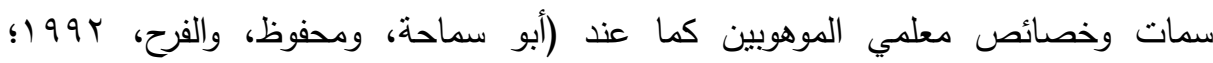

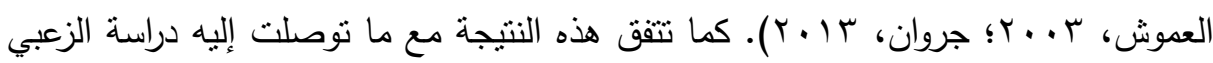

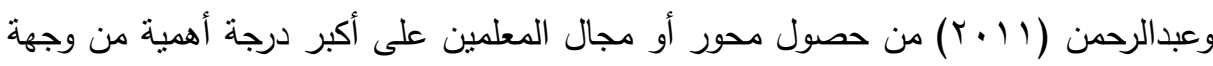
نظر التناميذ الموهوبين. ويمكن تفسير كون المحور الأول الخاص بإدارة مراكز رعاية الموهوبين قد احتل المرتبة

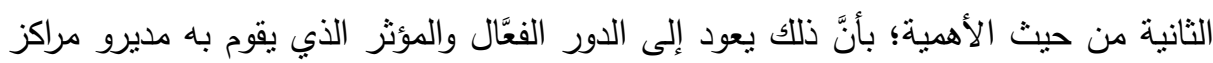

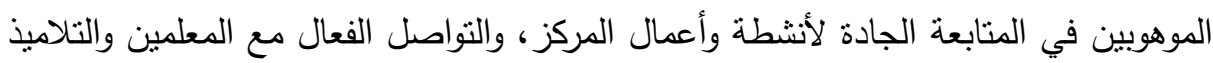

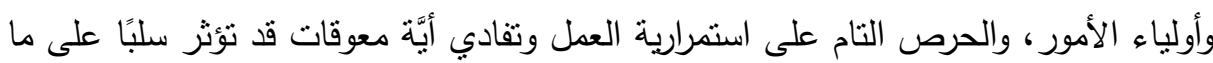
يوفّره مركز الموهوبين من خدمات للمرددين عليه من التلاميذ المتميزين. 
وتتقق هذه النتيجة مع ما توصلت إليه دراسة الزعبي وعبدالرحمن (11 + ؟) من حصول

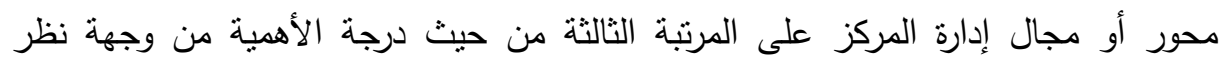
التلاميذ الموهوبين. ويعزو الباحث تلك النتيجة إلى أنَّ مديري مراكز الموهوبين نخبة متميزة

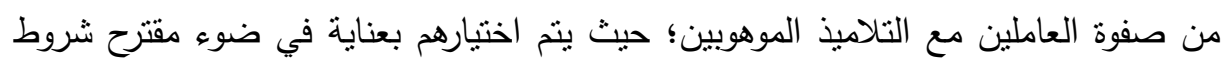
الترشيح والاختصاصات للوظائف والمنصوص عليه في النشرة التوجيهية الخاصة بالإدارة

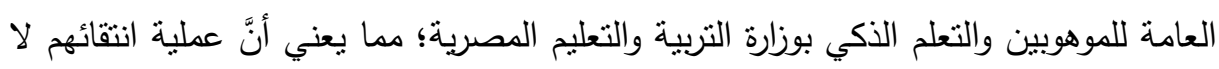

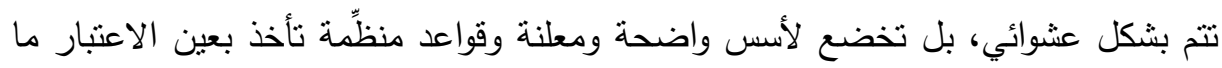

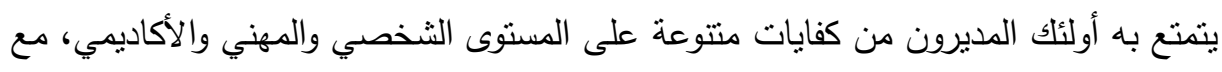
الاهتمام بالحصول على دورات تدريبية في مجال الموهوبين.

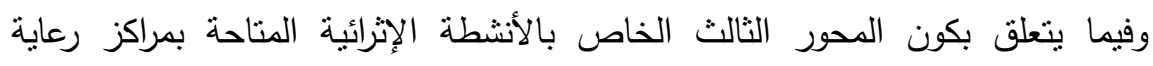

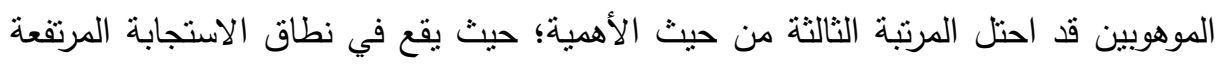

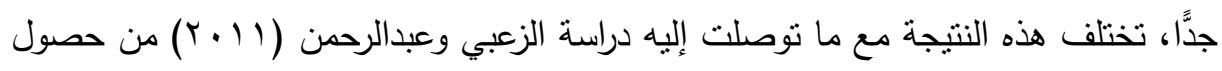
محور أو مجال الأنشطة الإثرائية المتاحة بمراكز رعاية الموهوبين على المرتبة الرابعة والأخيرة من حيث درجة الأهمية من وجهة نظر التلاميذ الموهوبين. ويمكن تفسير ما توصل إليه البحث الحالي في ضوه ماء ما نقدّمه مراكز رعاية الموهوبين

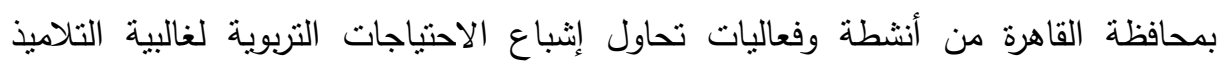

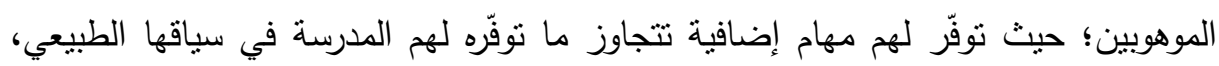
كما أنَّ هذه الأنشطة تتطابق مع ميول واهتمامات معظم التلاميذ المترددين على مراكز الموهوبين ويُفضي هذا التطابق بين الأنشطة المتاحة وميول التلاميذ إلى استثارة دافعية

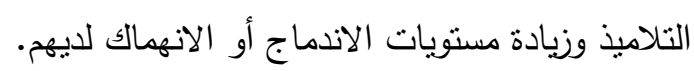

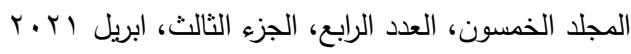

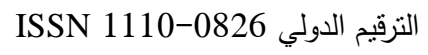


ومن الجدير بالذكر أن المحور الثالث الخاص بالأنشطة الإثرائية المتاحة بمراكز رعاية

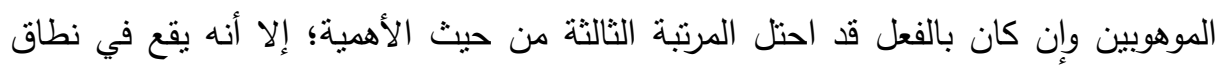

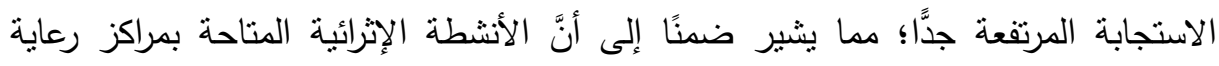

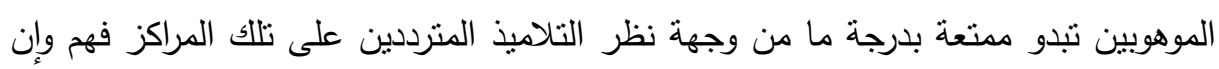

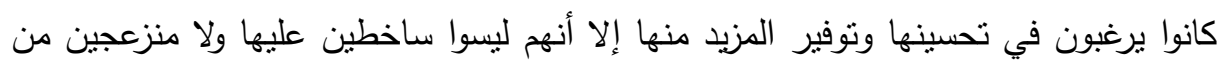

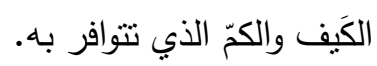

ويمكن تفسير كون المحور الرابع الخاص بخصائص وإمكانات مراكز رعاية الموهوبين قد بلد

احتل المرتبة الأخيرة من حيث الأهية؛ حيث يقع في نطاق الاستجابة المرتفعة، بأن ذلك الك الكان

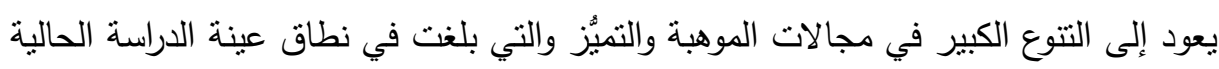

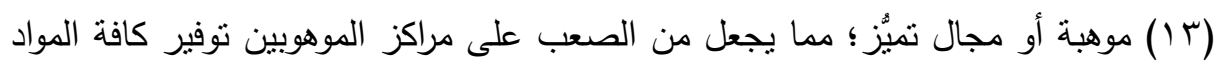

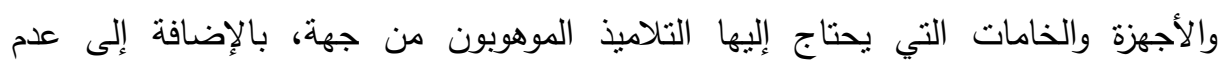
تخصيص أماكن مستقلة لعدد كبير من مراكز الموهوبين؛ إذ يتم تخصيص إحدى القاعات

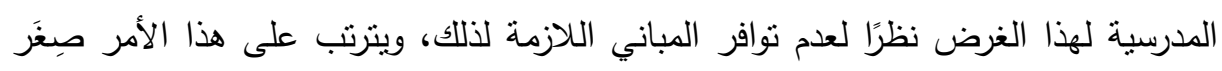
مساحة المكان المخصص للمركز وعدم جاهزيته بالثكل الذي يلبي طموحات التلاميذ الموهوبين ويُشبع احتباجاتهم التربوية الفائقة.

ويمكن أن يعزو الباحث تلك النتيجة إلى ضَعْفَ مشاركة المجتمع المحلي في دعم مراكز

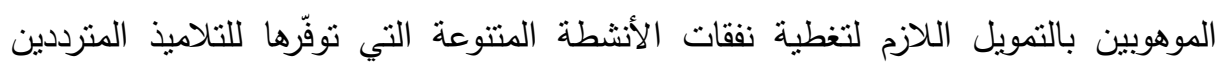
عليها؛ مما يضطر إدارات تلك المراكز إلى نوفير المواد والخامات والأجهزة الأكثر طلبًا؛ أي لئي

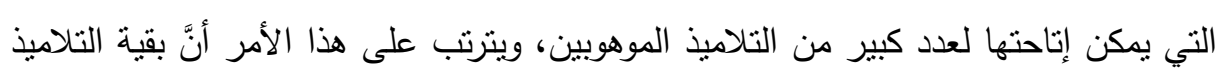
لا يجدون ما يحتاجون إليه من المواد والخامات والأجهزة. 
ومن الجدير بالذكر أن المحور الرابع الخاص بخصائص وإمكانات مراكز رعاية الموهوبين وإن كان بالفعل قد احتل المرنبة الأخيرة من حيث الأهمية؛ إلا أنه يقع في نطاق

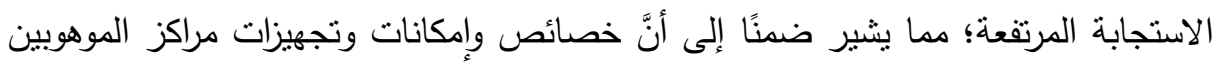

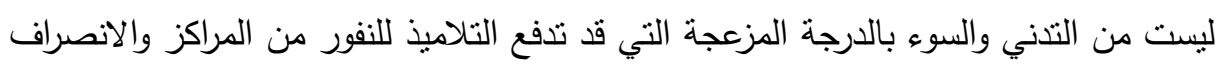
عن الحضور إليها، وبالتالي، يتطلع التلاميذ الموهوبون لمزيد من تطوير تلك المراكز ولكنهم

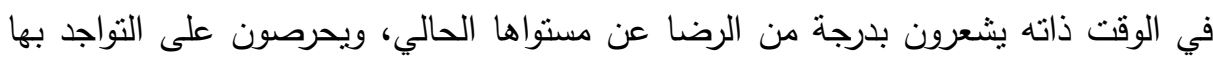
والتردد عليها بانظظام للمشاركة في أنشطنها وفعالياتها المنتوعة. وفيما يتعلق بما كثفت عنه نتائج التحليل الإحصائي لأداة الدراسة من أن مجمل محاورة

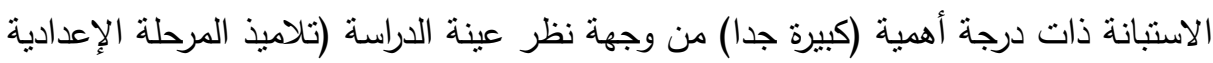

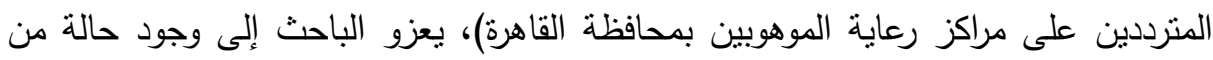
التناغم بين عناصر منظومة العمل في هذه المراكز بدايةً من مديري المراكز الذين ينت

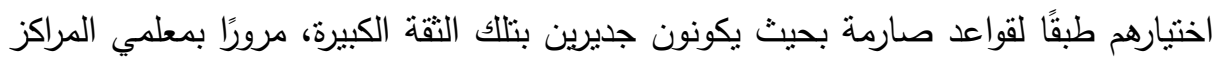

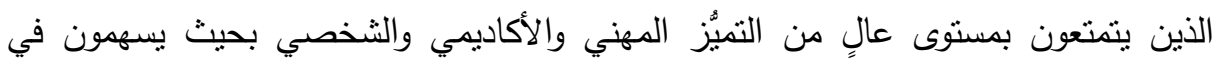

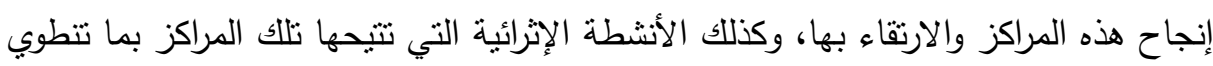

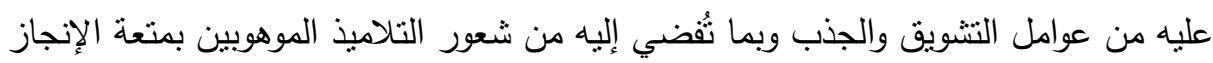

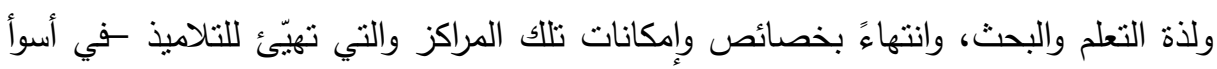

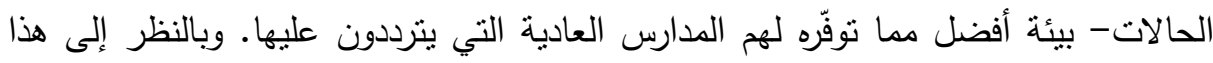
التتاغم الحادث بين تلك العناصر الأربعة بثَّضح أنَّ استجابات عينة الدراسة نقدّم صورة واقعية موضوعية لوصف الأجواء التي يعيشها التلاميذ الموهوبون في رحاب تلأك المراكز التي لأني خُصِّصت لهم دون غيرهم من التلاميذ.

$$
\begin{aligned}
& \text { المجلد الخمسون، العدد الرابع، الجزء الثالث، ابريل اب • ب }
\end{aligned}
$$

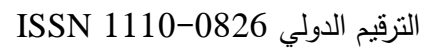


ب- النتائج الخاصة بترتيب العبارات داخل كل محور من محاور الاستبانة حسب الوزن النسبي:

للحصول على ترتيب عبارات الاستبانة من وجهة نظر عينة الدراسة قام الباحث

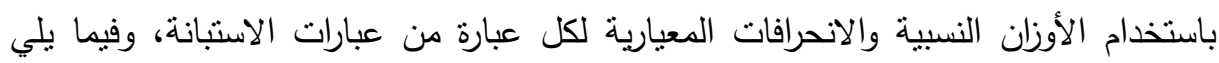
عرض لنتائج كل محور من محاور الدراسة على حدة:

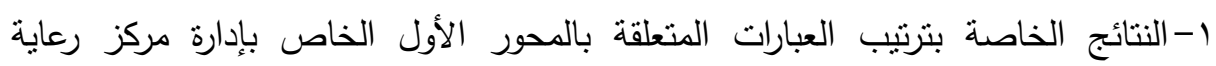
الموهوبين حسب أوزانها النسبية: بنزية

أوضحت نتائج الدراسة أن منوسط الأوزان النسبية لعبارات المحور الأول الخاص بإدارة

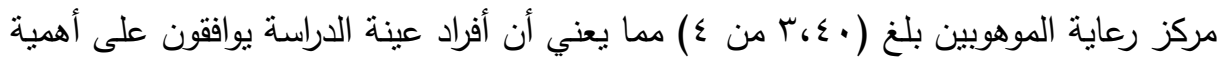

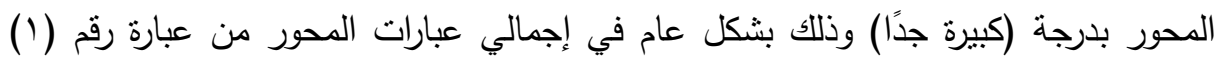

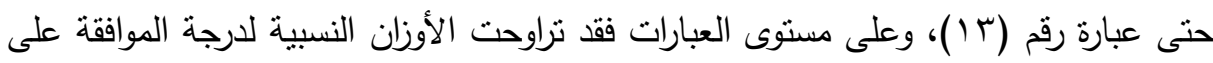

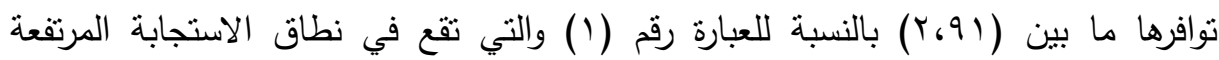

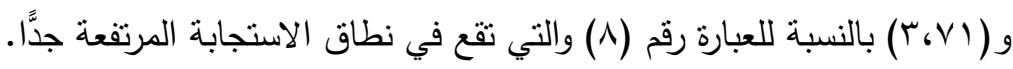

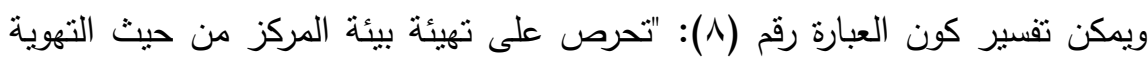
والإضاءة" قد احتلت المرتبة الأولى من حيث الأهمية؛ حيث يقع وزنها النسبي في نطاق

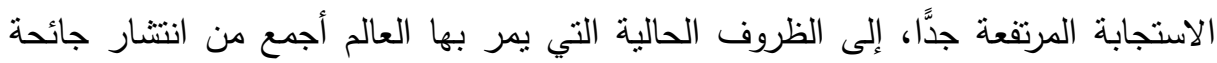
فيروس كورونا المستجد COVID-19، وما ترتَّب على تللك الجائحة من تداعيات وإجراءات احترازية وتدابير وقائية؛ حيث تسببت في إثارة انفعالات عديدة وضغوط قوية، بما في ذلك التباعد الاجتماعي، والحَجْر الصحي، وحظر التجوُل، وغيرها من الظروف غير المواتية التي

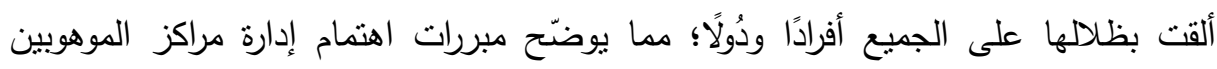
بالإتشراف المباشر والمتابعة المستمرة لمنل هذه الإجراءات والتدابير استشعارًا لمسئوليتهم أمام 
الله عز وجل أولا ثم أمام المجتمع والقانون ثانيًا، فالتلاميذ الموهوبون المترددون على المراكز أمانة في أعناقهم، وينبغي عليهم الحرص على سلامتهم وصحتهم، ويتحقق ذلك بتعقيم المركز وتهويته وتجنب التزاحم أثناء تأدية أنشطته وتتفيذ فعالياته، فخدمة التناميذ الموهوبين وإن كانت مهمة للغاية إلا أن سلامتهم وصحتهم أهم بكثثر .

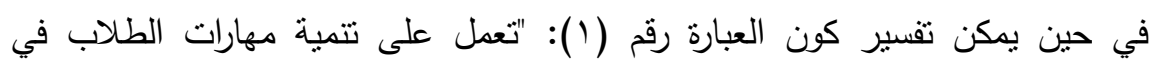

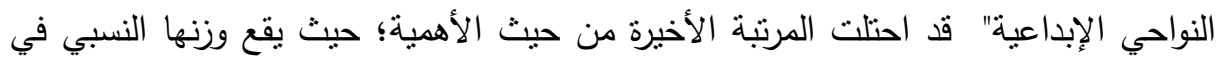

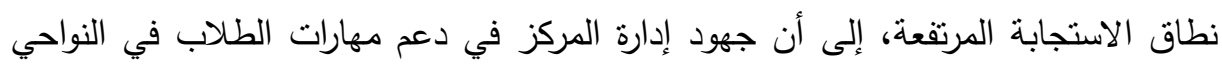

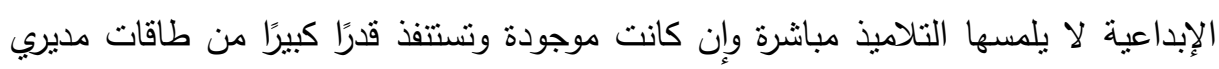
المراكز ، فجهود أولئك المديرين ثُبَّل في التخطيط والتتسيق والإتشراف والمتابعة وكلها مهام

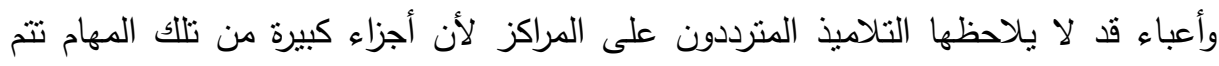

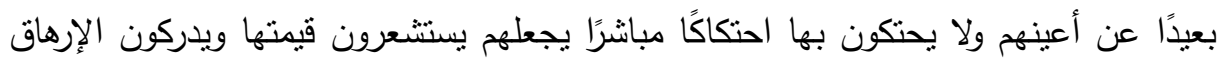
الناتج عنها. r-النتائج الخاصة بترتيب العبارات المتعلقة بالمحور الثاني الخاص بمعلمي مركز رعاية الموهوبين حسب أوزانها النسبية:

أوضحت نتائج الدراسة أن منوسط الأوزان النسبية لعبارات المحور الثاني الخاص

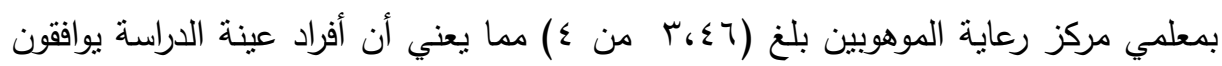

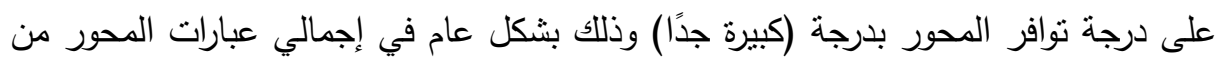

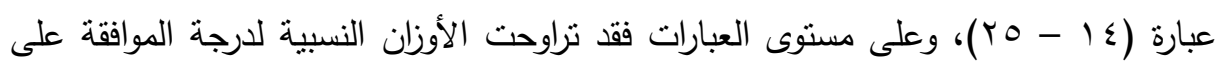

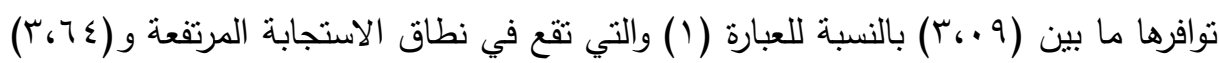
بالنسبة للعبارة (V) والتي تقع في نطاق الاستجابة المرتفعة جدًا.

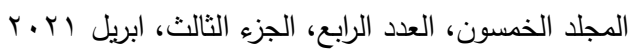

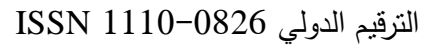


ويمكن تفسير كون العبارة رقم (V): "يلفتون نظر الطلاب عند ممارسة سلوكيات بيئية غير سليمة" قد احتلت المرنبة الأولى من حيث الأهمية؛ حيث يقع وزنها النسبي في نطاق

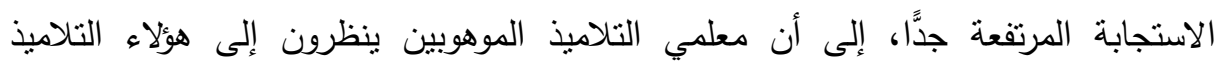

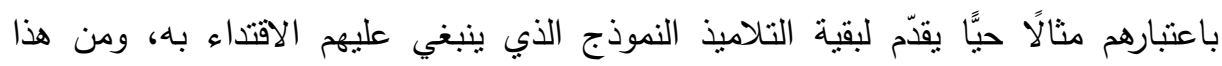

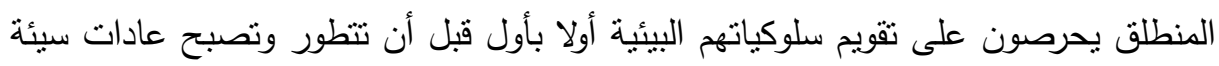
راسخة يصعب تعديلها، ويأني حرص المعلمين على ذلك من قبيل أنه لا يجوز تأخير البيان

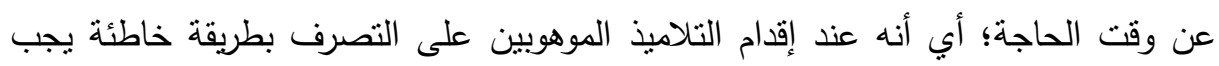
توضيح الصواب لهم وإرشادهم إلى السلوك المناسب فورًا.

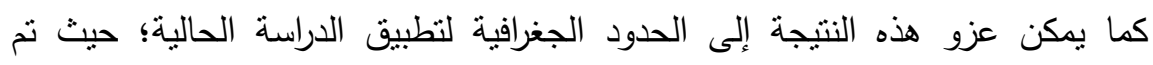
تطبيقها في بعض مراكز الموهوبين التابعة لمحافظة القاهرة، والقاهرة باعتبارها عاصمة البلاد، لئه

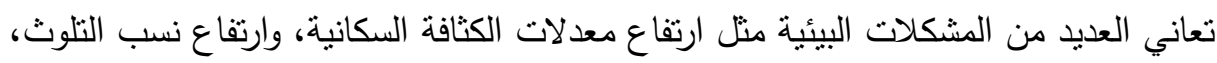

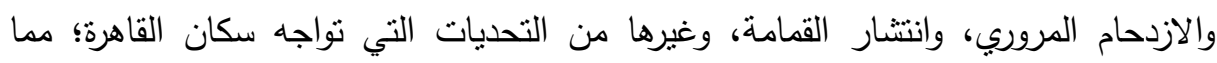
يجعل المنقفين والمستتيرين من السكان إلى مقاومة منل تلك الظواهر السلبية التي تضر البيئة وتتعكس سلبًا على حياة المواطنين القاطنين بالعاصمة؛ وبالنظر إلى معلمي مراكز الموهوبين

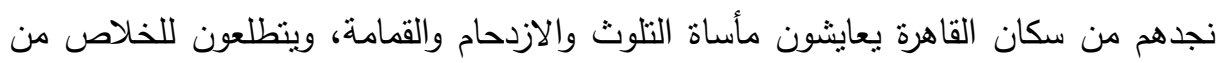

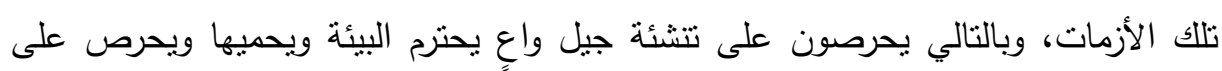
تتميتها.

في حين يمكن تفسير كون العبارة رقم (1): "يساعدون الطلاب على تتمية مواهبهم في

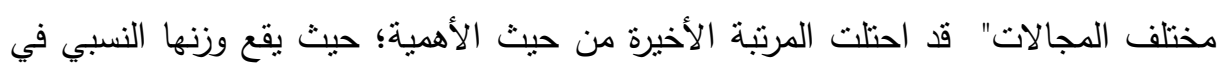

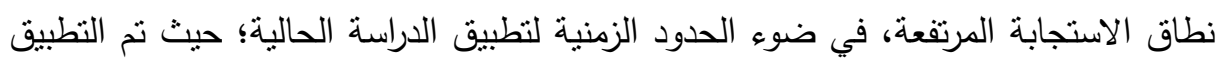

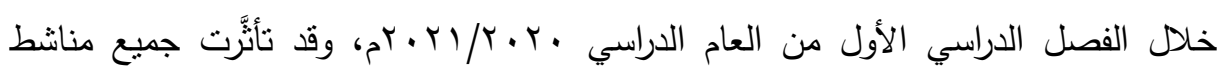

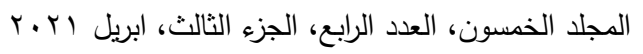

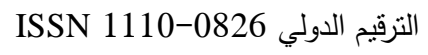


الحياة بأزمة كورونا، لا سيما بعد أن تسيَّبت في تعليق الدراسة خلال الفصل الدراسي الثاني

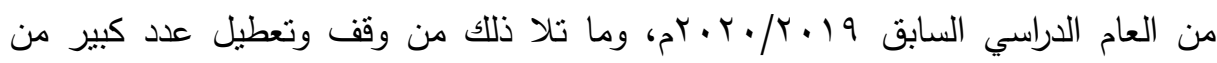
الفعاليات والأنشطة التي تقتضي التواجد في تجمعات، ومن هنا فإن التلاميذ الموهوبين عندما يعبّرون عن عدم رضاهم عن مستوى مشاركة المعلمين في تتمية المواهب التي يمتلكها التلاميذ، فإنهم يعقدون مقارنة بين ما كان عليه المعلمون قبل جائحة كورونا وما هم عليه فئيه الآن، وهي مقارنة يشوبها سوء الفهم وتتطوي على مغالطة كبيرة؛ حيث إن إنهان الأجواء غير في

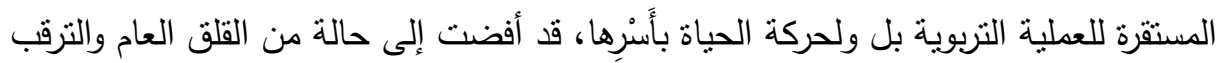

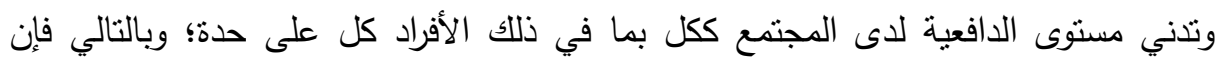
معلمي مراكز الموهوبين لديهم عذرهم في ظل القلق المتصاعد بشأن انتشار العدوى وزيادة

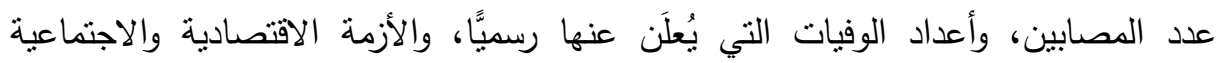

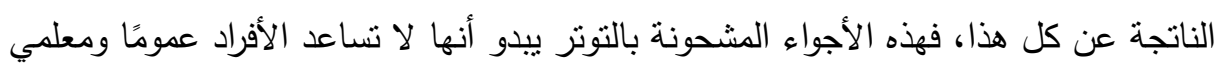

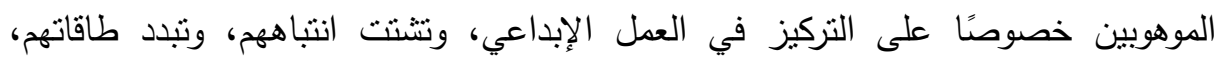
وتطفئ جذوة حماسهم شيئًا فنشينًا. r-النتائج الخاصة بترتيب العبارات المتعلقة بالمحور الثالث الخاص بالأنشطة الإثرائية المتاحة بمركز رعاية الموهوبين حسب أوزانها النسبية:

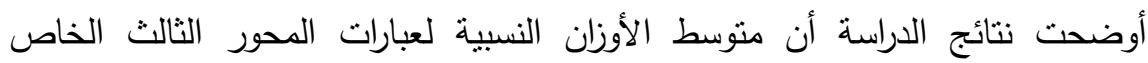
بالأنشطة الإثرائية المتاحة بمركز رعاية الموهوبين بلغ (ع ب، من ع ع) مما يعني أن أفراد عينة

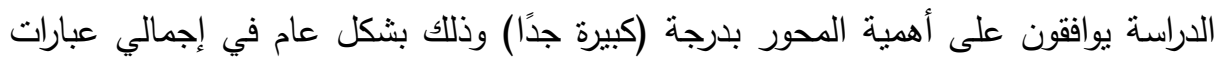

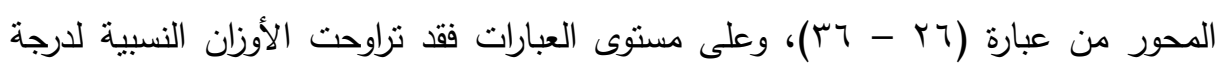

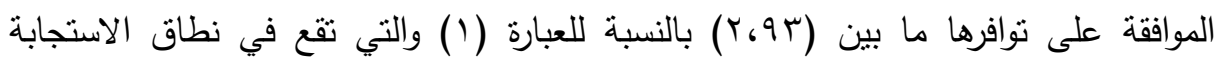

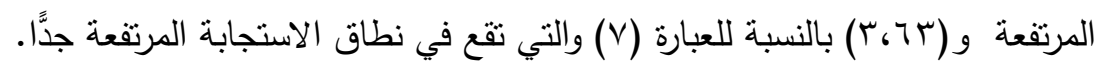

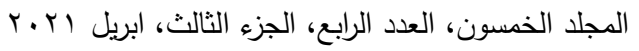

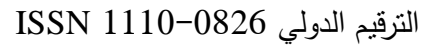


ويمكن تفسير كون العبارة رقم (V)): "تزيد من مستوى الوعي البيئي لدى الطلاب" قد

احتلت المرتبة الأولى من حيث الأهمية؛ حيث يقع وزنها النسبي في نطاق الاستجابة المرتفعة جدًا، إلى تزايد اهتمام الدولة بقضايا البيئة مؤخرًا، وإطلاق عدد من حملاتهات الإنهات التوعية البيئية

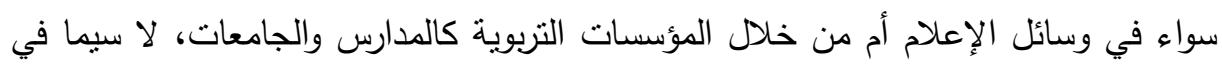
ظل الآثار السلبية الثديدة التي قد يُفضي إليها الاعتداء على البيئة والإخلال بالتوازن البيئي وإهدار الموارد الطبيعية، فبالنسبة لاستهلاك المباه يمثّل سد النهضة الأثثوبي تحديًا كبيرًا يهدّد أمن مصر المائي، ويستلزم من المصريين ضرورة تعديل سلوكياتهم الخاطئة في استهلاك فئك

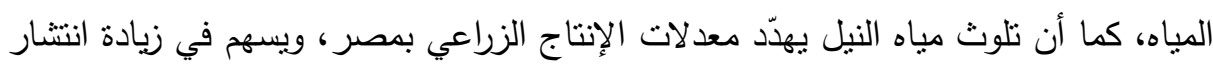
الأوبئة والأمراض، وغيرها من المشكلات التي ينبغي زيادة وعي التلاميذ الموهوبين بها.

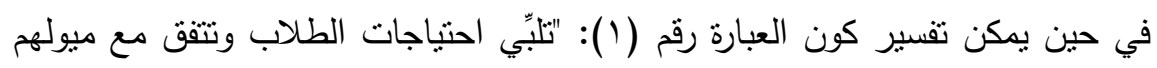

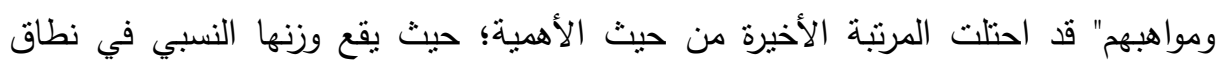
الاستجابة المرتفعة، إلى عدم تطوير أو تحديث النشرة التوجيهية الخاصة بالإدارة العامة

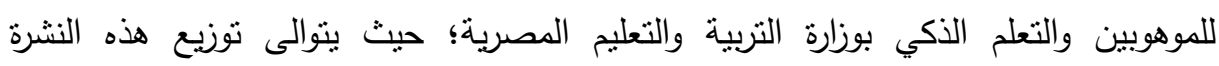

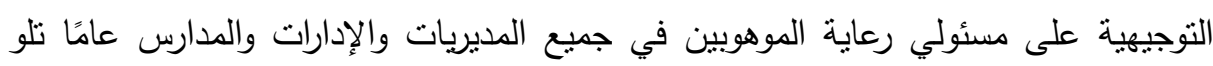

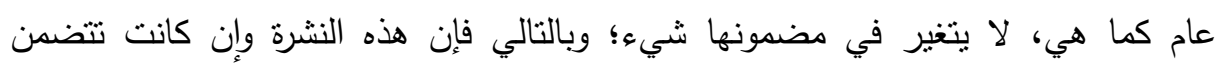

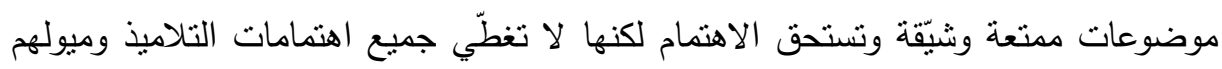

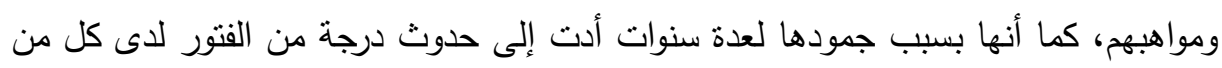

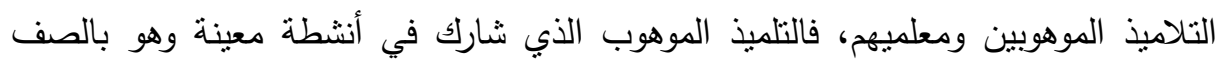

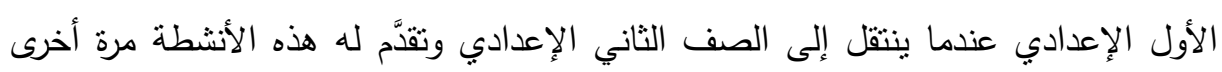

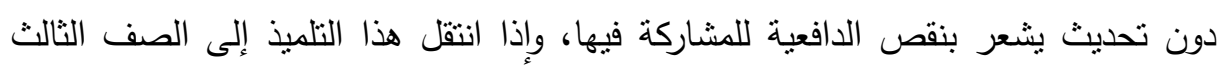

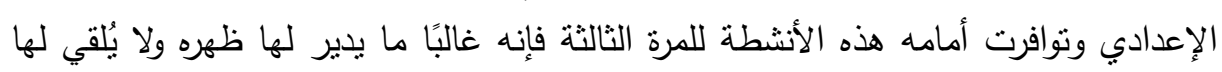


بالًا؛ لأنها فقدت قيمتها ومغزاها بالنسبة له، وهو مُحقِّ في ذلك، فالموضوعات التي يتم

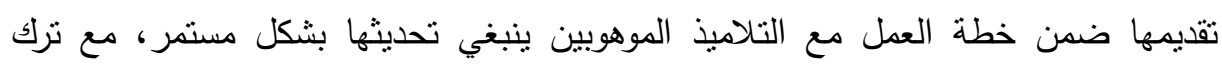

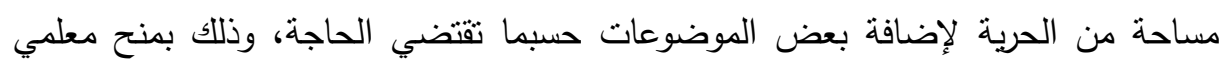
المراكز مزيد من الصلاحيات التي تتيح لهم القيام بمنل هذا الإجراء.

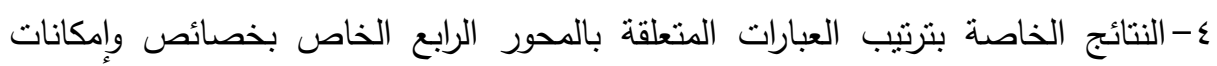
وتجهيزات مركز رعاية الموهوبين حسب أوزانها النسبية:

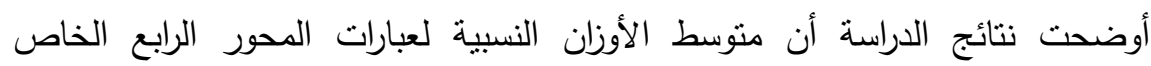

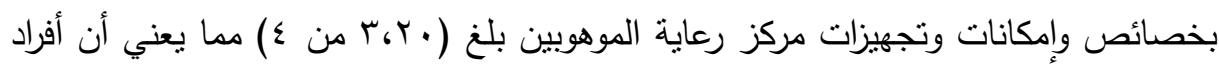

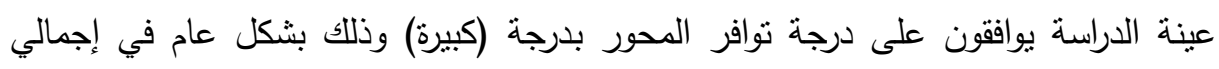
عبارات المحور من عبارة (Vr - .0)، وعلى مستوى العبارات فقد نراوحت الأوزان النسبية

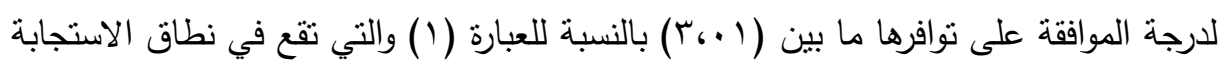

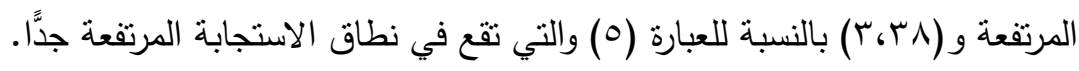

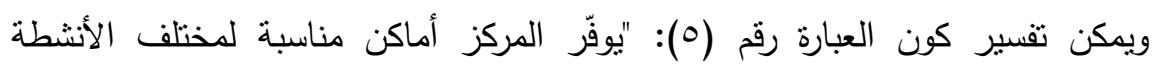

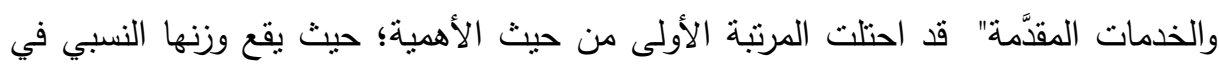
نطاق الاستجابة المرتفعة جدًا، بأن القائمين على مراكز رلاولى رعاية الموهوبين (مديري المراكز ، والمعلمين) قد نجحوا في تكييف بيئة العمل داخل هذه المراكز بحيث يمكن إجراء التعديلات

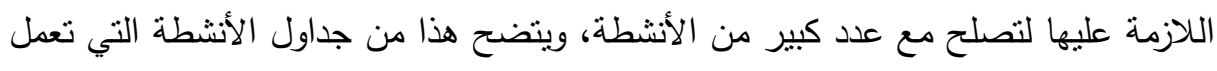

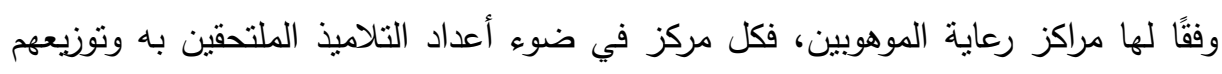

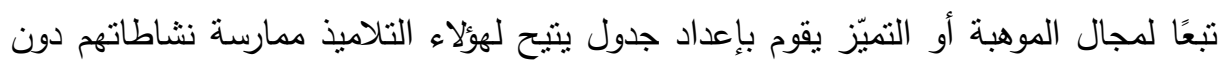

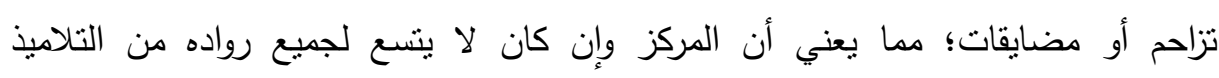

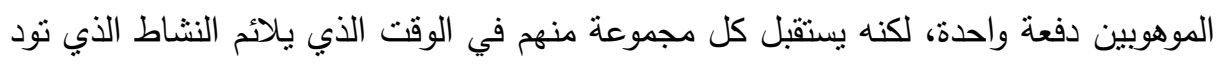

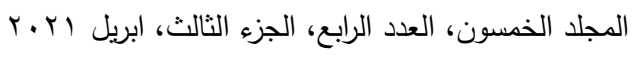

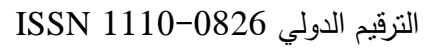


أن تمارسه فيشعر كل تلميذ وكأن المركز مسخَّر بالكامل للأنشطة الني يحبها هو وللخدمات التي يحصل عليها.

في حين يمكن تفسير كون العبارة رقم (1): "يشغل المركز مساحة جغرافية مناسبة

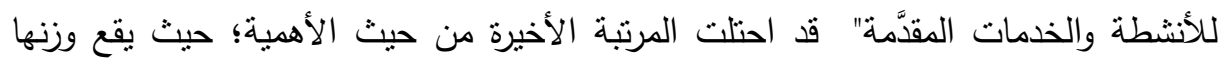

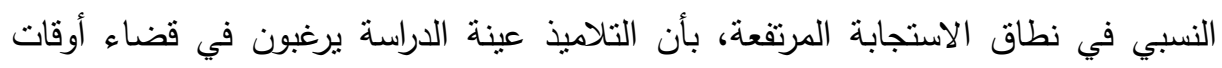

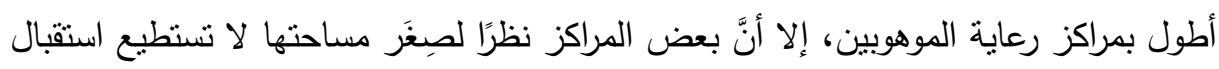
أولئك التلاميذ طوال الوقت ولا نستطيع استقبالهم في آن واحد؛ مما يجعل التناميذ يشعرون بدرجة معينة من عدم الرضا عن مساحة المركز ؛ فهي من وجهة نظرهم تثق عقبة أو عائقًا بينهم وبين الحضور في أب وقت والاستمرار في التواجد بالمركز لأي وقت، إلا أن استجابات

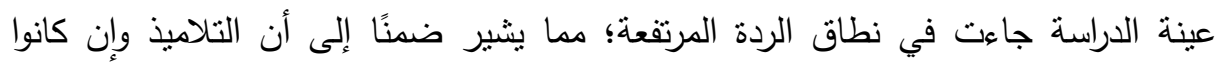

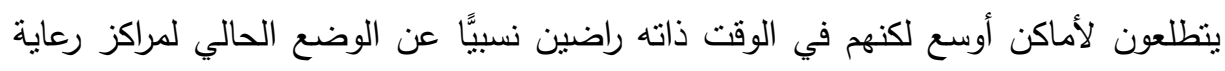

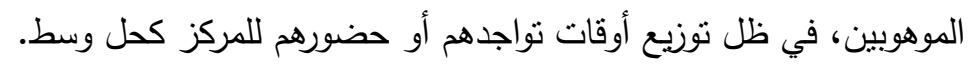

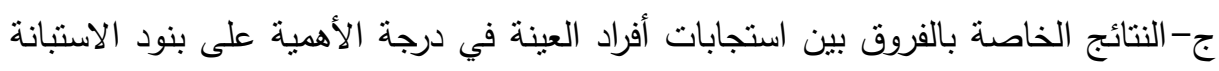

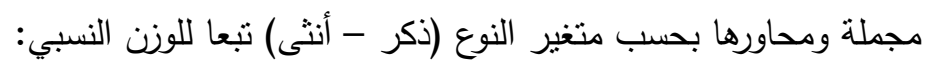

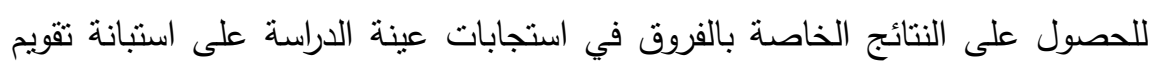
دور مراكز الموهوبين في تتمية السلوك البيئي والإبداعي لدى تلاميذ المرحلة الإعدادية تبعًا

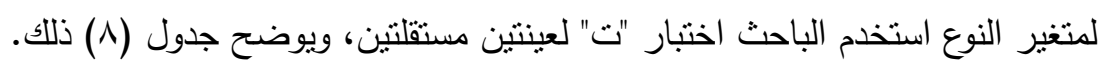


جدول (^):

\begin{tabular}{|c|c|c|c|c|c|c|}
\hline مستوى الالالة & قيمة "ت" & الانحراف & الحستوسط & العدد & المجموعة & المتغير \\
\hline \multirow{2}{*}{ 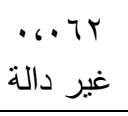 } & \multirow{2}{*}{$16 \wedge \vee T$} & $r_{6} r$. & $\leq 0,+1$ & NI & ذكور & \multirow{2}{*}{ المحور } \\
\hline & & 0.9. & $\varepsilon r .77$ & 119 & إناث & \\
\hline \multirow{2}{*}{ 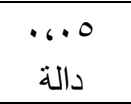 } & \multirow{2}{*}{$* Y_{6} T V \leq$} & r.70 & $\varepsilon r_{6} \leqslant Y$ & $\Lambda 1$ & ذكور & \multirow{2}{*}{ الثحور } \\
\hline & & 0.01 & $\varepsilon \cdot .9 r$ & 119 & إناث & \\
\hline \multirow{2}{*}{ 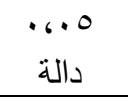 } & \multirow{2}{*}{ *Y ${ }_{6}$ Yq } & r.VT & rv, & $\Lambda 1$ & ذكور & \multirow{2}{*}{ الثالثور } \\
\hline & & 0.91 & 176.9 & 119 & إناث & \\
\hline \multirow{2}{*}{ غير دالة } & \multirow{2}{*}{.691.} & $\left.\Lambda_{6}\right) \mathrm{V}$ & $\varepsilon 0.7 Y$ & $\wedge 1$ & ذكور & \multirow{2}{*}{ الرحور } \\
\hline & & 9617 & 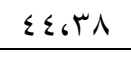 & 119 & إناث & \\
\hline \multirow{2}{*}{ 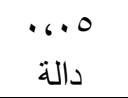 } & \multirow{2}{*}{$* r_{6} \cdot r_{q}$} & $1 \pi, 94 \varepsilon$ & $1 V \cdot . \wedge \leq$ & 11 & ذكور & الاستبانة \\
\hline & & $r r_{6} \Lambda \cdot V$ & 1706.0 & 119 & إناث & ككل \\
\hline
\end{tabular}

وكما يتضح من جدول (^) فقد كثفت النتائج عن عدم وجود فروق دالة إحصائَّاً بين متوسطي درجات مجموعتي (الذكور والإناث) في الاستجابة على كل من المحور الأول (إدارة مركز الموهوبين) والمحور الرابع (خصائص وإمكانات مركز الموهوبين)، حيث بلغت قيمتا

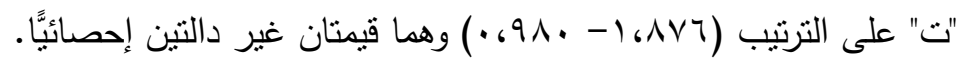

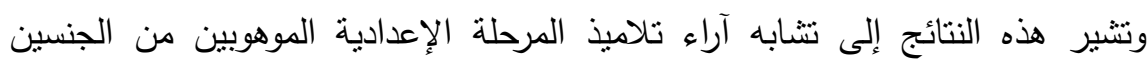

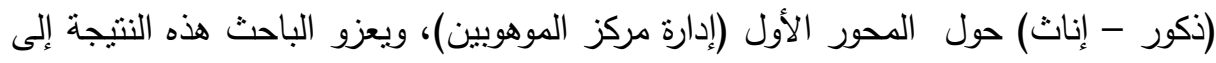

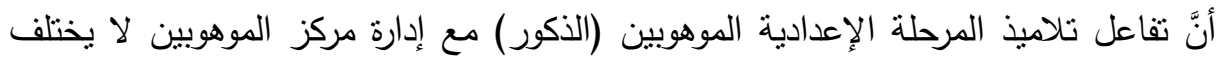

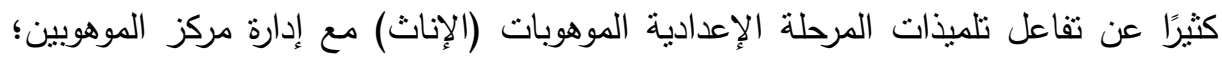
حيث إنَّ إدارة مركز الموهوبين تلتقي بجميع التلاميذ والتلميذات وتقدّم لهم الخدمات بنفس الإدات

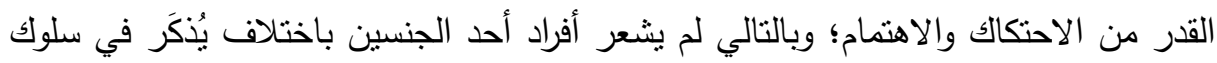


وجهود إدارة مركز الموهوبين، ويرى الباحث الحالي أنَّ هذا الأمر يعد نجاحًا لإدارة مركز الموهوبين.

وتتثير هذه النتائج إلى تثابه آراء تلاميذ المرحلة الإعدادية الموهوبين من الجنسين

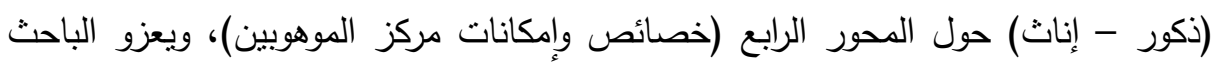
هذه النتيجة إلى أنَّ خصائص وإمكانات مركز الموهوبين من حيث التجهيزات والبيئة الفيزيقية

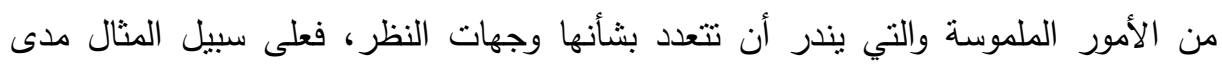
ملاءهة أو عدم ملاءمة مساحة المركز للأنشطة المقدَّمة من خلاله تعد مسألة واضحة

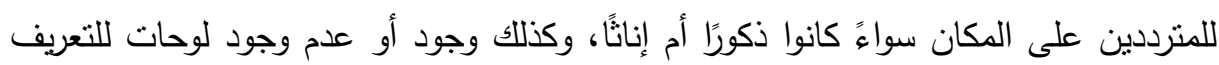

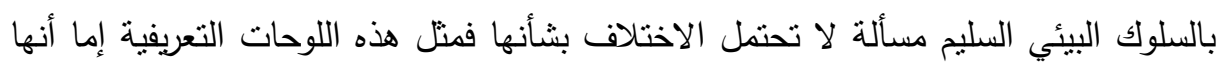
موجودة بالمركز أو غير موجودة.

في حين أظهرت النتائج وجود فروق دالة إدودة إحصائيًا عند مستوى (0.، • ) بين متوسطي درجات مجموعتي (الذكور والإناث) في الاستجابة على كل من المحور الثاني (معلمو مركز

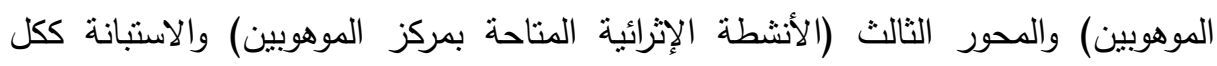

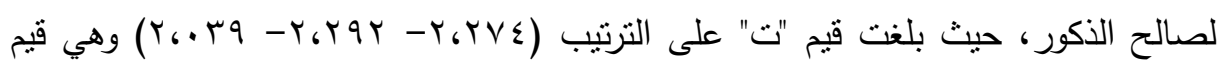
دالة إحصائيًا عند مستوى دلالة (0. ، . •).

وتتشير هذه النتائج إلى تباين آراء تلاميذ المرحلة الإعدادية الموهوبين من الجنسين (ذكور - إناث) حول المحور الثاني (معلمو مركز الموهوبين)، والمحور الثالث (الأنشطة الإثرائية

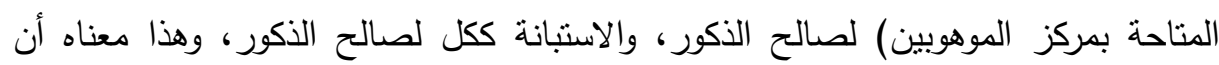
الأكور أكثر رضا عن أداء معلمي مركز الموهوبين كما أنهم أكثر رضا عن الأنشطة المتاحة

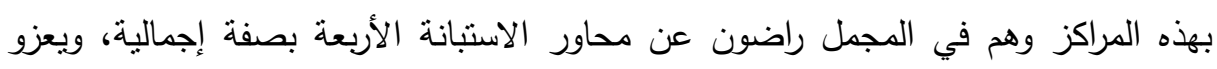

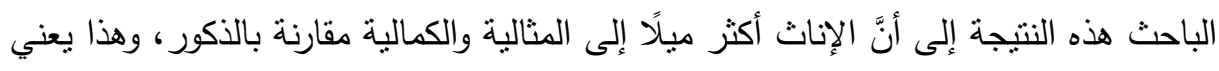


أنَّ ما يحصل على رضا وتقدير الذكور بدرجة كبيرة قد لا يحصل على رضا وتقدير الإناث

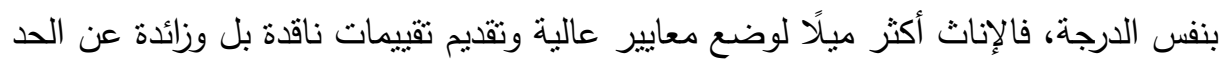

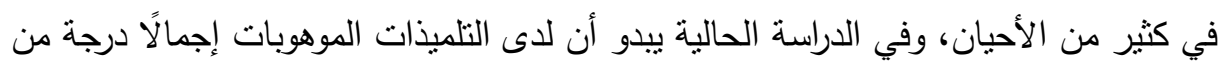

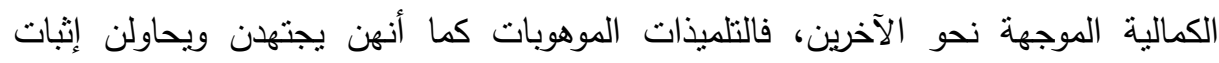
ذواتهن والتقوق على أنفسهن فإنهن في الوقت ذاته يتوقعن من الآخرين أن يسلكوا المسلك ذاته؛ ومن ثم بتطلعن دائمًا إلى ما هو أفضل مع إنى في انتقاد الوضع القائم، وفي الدراسة الحالية يمكن تفسير ذلك بأن التلميذات الموهوبات ينتظرن من معلمي المركز أكثر مما يتم تقديمه

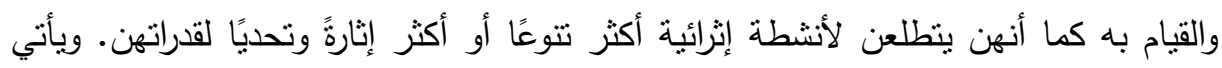

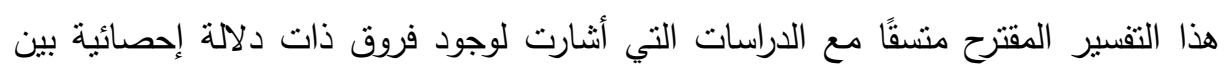

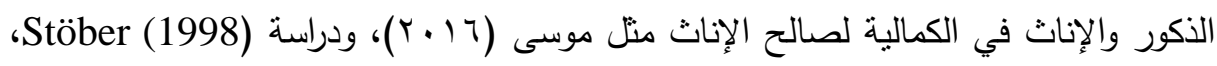

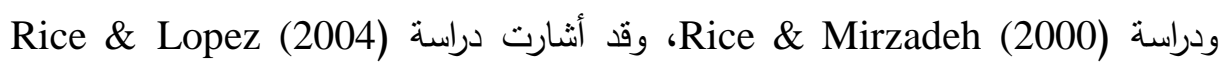
لوجود لوجود فروق ذات دلالة إحصائية بين الإناث المتفوقات وقريناتهن غير المتفوقات في الكمالية لصالح الإناث المتفوقات.

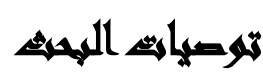

واختتم البحث بالتوصيات والمقترحات الآتية: •بناء برامج توعوية وتثقيفية للتلاميذ الموهوبين وأولياء أمورهم؛ للتعريف بالأدوار المنميزة بالتية

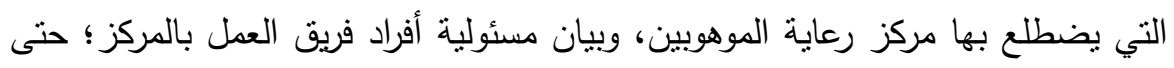
يستشعر التلاميذ وأولياء أمورهم حجم الجهد المبذول.

• ضرورة تصميم الأنشطة الإثرائية المتاحة بمراكز رعاية الموهوبين في ضواء الجئ أفضل الممارسات التربوية المستتدة إلى الدليل والبحث العلمي في مجال الموهبة والإبداع

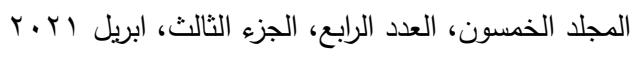

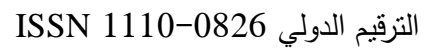


والتقوق، بحيث تعبّر هذه الأنشطة عن أفضل ما توصّل إليه الخبراء والباحثون في الميدان.

• عقد المزيد من الدورات التدريبية المكثفة لمعلمي مراكز رعاية الموهوبين لتمكينهم من التمان

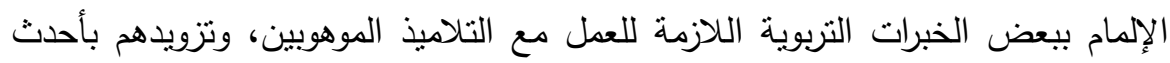
المستجدات في مجال تعليم الموهوبين والمتفوقين.

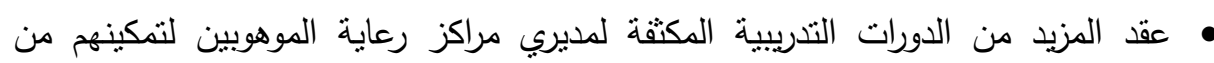

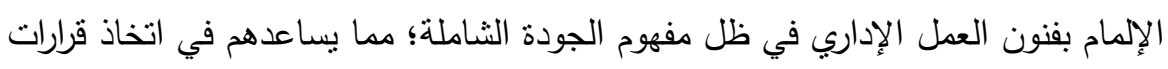
إبداعية لتحسين بيئة العمل بالمراكز ، وتوطيد العلاقات مع كافة الأطراف المعنية.

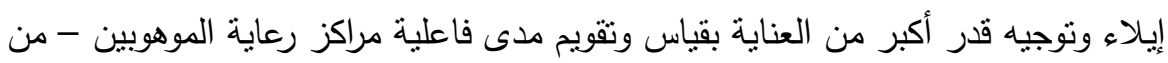

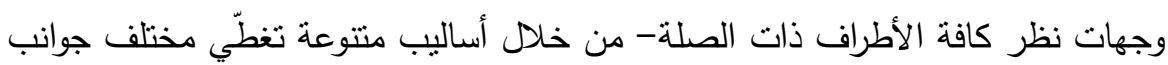

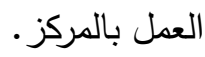
• تحسين ميزانيات مراكز رعاية الموهوبين من خلال مصادر تمويل منتوعة بحيث تنتح

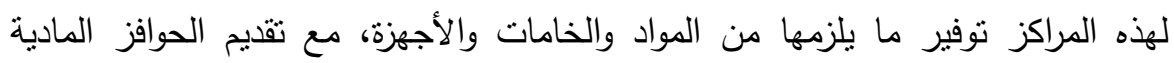
لتشجيع طاقم العمل على بذل مزيد من الجهد، وإثشعارهم بالتقدير، وتوفير لهنير الجوائز التتجيعية والمكافآت المجزية للتلاميذ الموهوبين لتتجيعهم على تتمية مواهبهر وتعزيز جهودهم. تخصيص مباني مستقلة لمراكز رعاية الموهوبين، يتم بنائها وفق تصممي هندسي

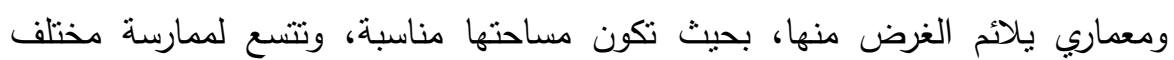
الأنشطة والفعاليات المستهدفة. 
ه استطلاع آراء التلاميذ الموهوبين حول احتباجاتهم التربوية والتدريبية؛ لزيادة دافعية التلاميذ وإقبالهم على المشاركة في أنشطة المركز ، وتتمية اتجاهات إيجابية لديهم نحو مكانتهم في المجتمع.

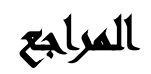

أبو سماحة، كمال ومحفوظ، نبيل والفرح، وجيه (ب991 (19): تربية الموهوبين والتطور التربوي.

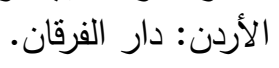

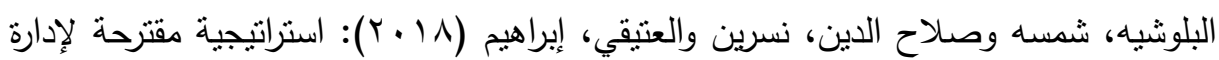

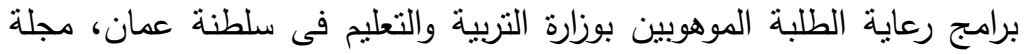

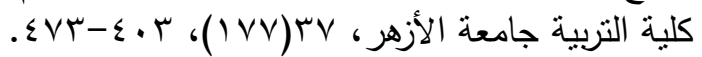

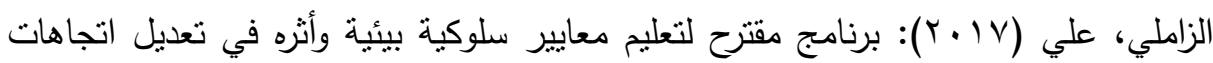

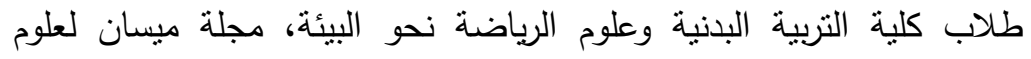

التربية البدنية، (7 (1).

الزعبي، سهيل وبني عبد الرحمن، مجدولين (11) (1): فاعلية مركز رعاية الموهوبين

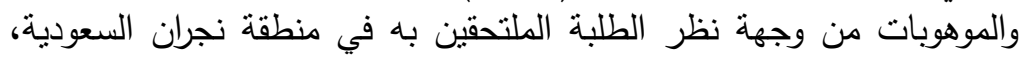

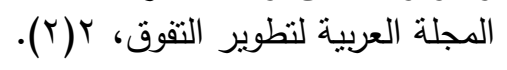

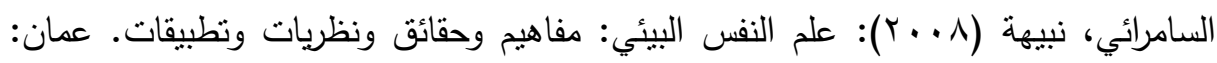

$$
\text { دار زهران. (- مان. }
$$

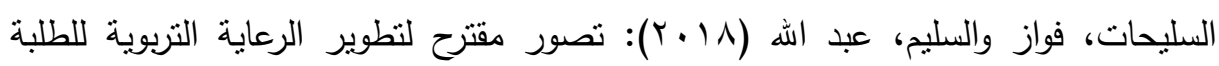

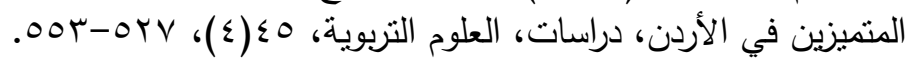

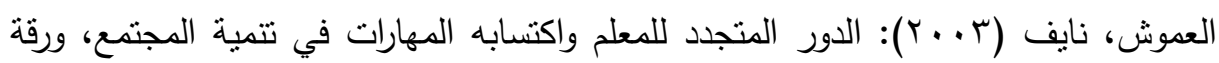

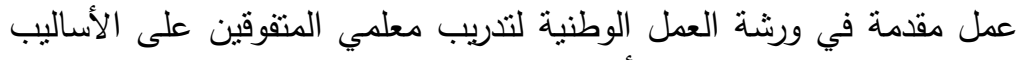

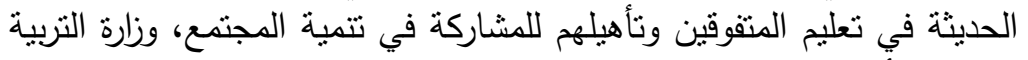

$$
\text { والتعليم الأرّدنية. }
$$

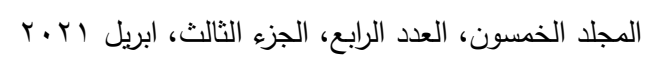

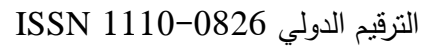




$$
\begin{aligned}
& \text { مجلة العلوم البيئية }
\end{aligned}
$$

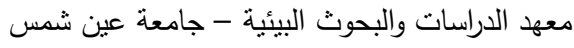

$$
\begin{aligned}
& \text { محمد عبد التواب عبد المولى وآخرون }
\end{aligned}
$$

المواش، إبراهيم (T 1 †): دور المدرسة المعززة للصحة في تتمية السلوك البيئي لدى الطلاب

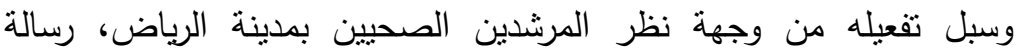
ماجستير غير منشورة، كلية العلوم الاجتماعية، جامعة الإمام محمد بن سعود المين

$$
\text { الإسلامية. }
$$

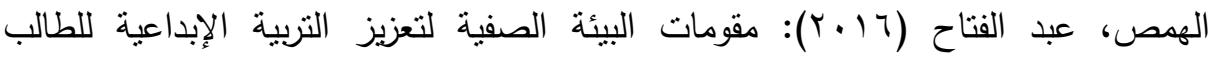

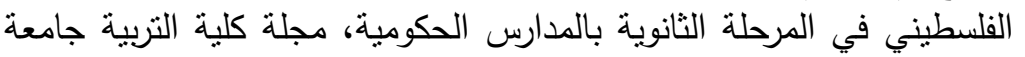

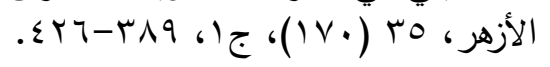

$$
\begin{aligned}
& \text { الهويدي، زيد (ع . ㄷ): الإبداع: ماهيته واكتثافه وتتميته. العين: دار الكتاب الجامعي. } \\
& \text { بدران، عمرو (Y.0 (Y): الثخصية المبدعة. القاهرة: مكتبة الأنجلو المصرية. }
\end{aligned}
$$

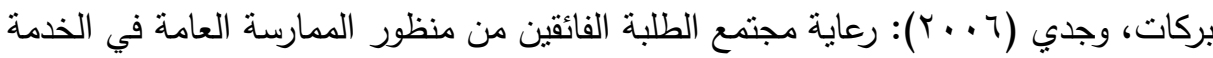

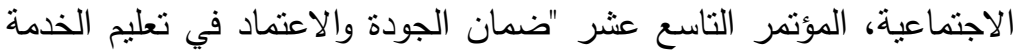

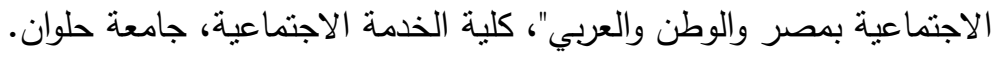

$$
\text { جروان، فتحي (r ( • ب): الموهبة والتفوق. الأردن: دار الفكر. }
$$

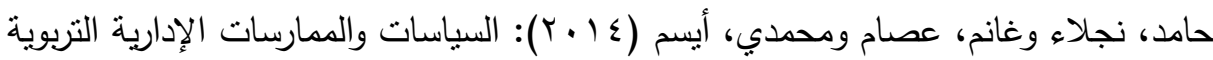

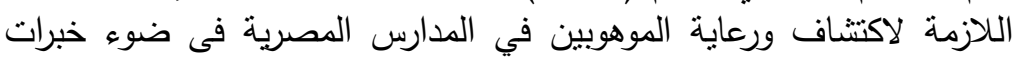

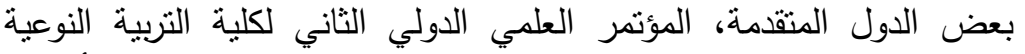

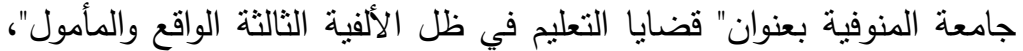

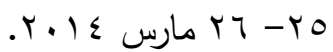

ضاهر، حنان (ع ( ب): السلوك البيئي في مرحلة المراهقة وعلاقته بالعجز المتعلم ومهنة

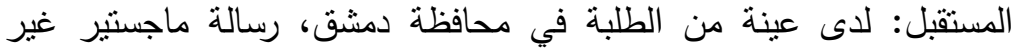

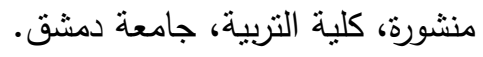

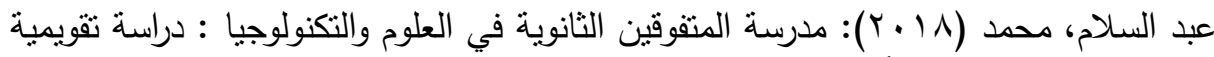
في ضوء أهدافها، رسالة ماجسنير غير منشورة، كلية التربية جامعة المنصورة النيا.

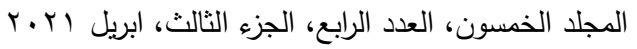

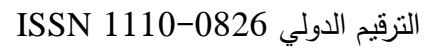




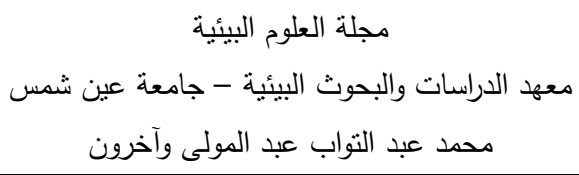

عشرية، إخلاص (9 (ب): دراسة تقويمية لبرنامج نخب رياض الأطفال بالسودان لتتمية الموهبة الإبداعية للطفل وفق المعايير العالمية، المجلة العربية للإعلام وثقافة بلانة

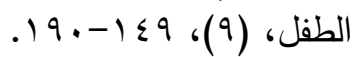

غانم، محمد (·.r.r): المختصر المفيد في علم النفس البيئي. القاهرة: مكتبة الأنجلو

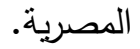

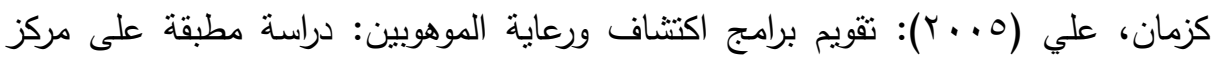

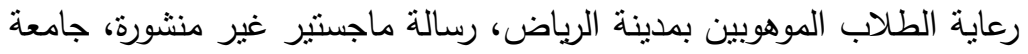
الإمام محمد بن سعود الإسلامية.

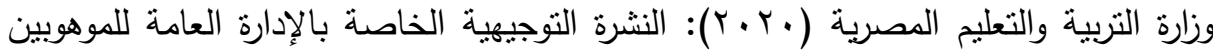

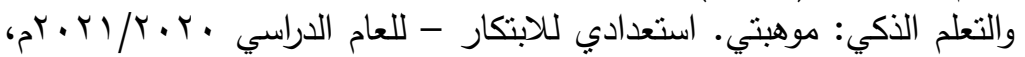

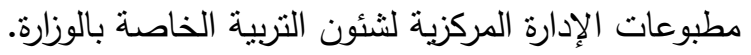

Aljughaiman, A. M. and Ayoub, A. E. A. (2012): The effect of an enrichment program on developing analytical, creative, and practical abilities of elementary gifted students. Journal for the Education of the Gifted, 35(2), 153-174.

Hidi, S., and Renninger, K. A. (2006): The four-phase model of interest development. Educational psychologist, 41(2), 111-127.

Mönks, F. J. and Pflüger, R. (2005): Gifted Education in 21 European Countries: Inventory and Perspective. Radboud University Nijmegen.

Murat, Ã. and GÃžlcan, Ã. (2018): Gifted and talented students' views about Biology activities in a science and art center. Science Education International, 29(1).

Park, H. J. (2008): Lived experiences of Korean gifted education teachers: A collective qualitative case study (Doctoral dissertation, Teachers College, Columbia University).

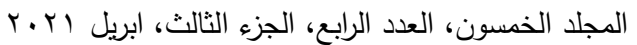

$$
\begin{aligned}
& \text { التزقيم الدولي 0826- ISSN 1110 }
\end{aligned}
$$




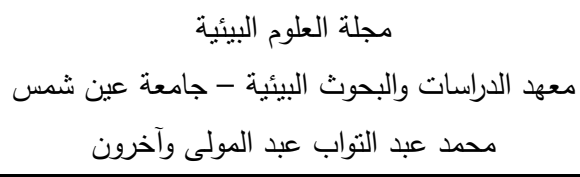

Trna, J. (2014): IBSE and Gifted Students. Science Education International, 25(1), 19-28.

VanTassel-Baska, J. and Stambaugh, T. (2005): Challenges and Possibilities for Serving Gifted Learners in the Regular Classroom, Theory into Practice, 44(3): 211-217.

\title{
AN EVALUATION STUDY OF THE ROLE OF THE GIFTED CENTER IN THE DEVELOPMENT OF ENVIRONMENTAL AND CREATIVE BEHAVIOR
} AMONG PREP SCHOOL STUDENTS

\section{Mohammad A. Abdel Maula(1); Mostafa I. Awad(2); Al-Shaymaa Badr ${ }^{(2)}$ and Safya Ahmed ${ }^{(2)}$}

1) Post graduate Student at Institute of Environmental Studies and Research, Ain Shams University 2) Institute of Environmental Studies and Research, Ain Shams University

\begin{abstract}
The aim of this research is to evaluate the role of gifted centers in developing environmental and creative behavior among middle school students. The research was based on the descriptive approach. The research sample consisted of (200) male and female middle school students during the first semester of the academic year 2020/2021. Of them (81) are males and (119) are females. To achieve the goal of the research, a questionnaire was prepared that includes (50) phrases covering four areas: The center's management. The center's teachers. The center's activities. The center's characteristics and capabilities.
\end{abstract}

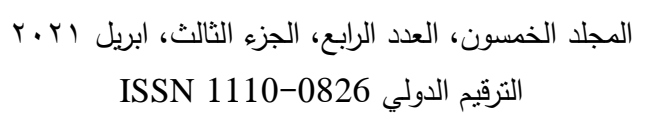




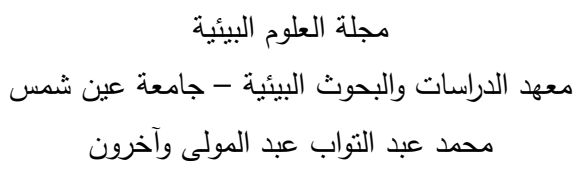

The results of the research indicated that the whole axes of the questionnaire have a degree of availability (very large) from the students' point of view, and the results of the research also revealed that there are no statistically significant differences between the mean scores of males and females in the response on both the first axis and the fourth axis, and the presence of statistically significant differences At the level of (0.05) between the mean scores of the two groups (males and females) in response to both the second and third axis, and the questionnaire as a whole in favor of males.

Key words: Gifted Centers - Environmental Behavior - Creative Behavior.

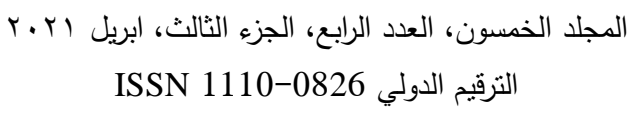

